\title{
Assessment and Mitigation Strategies to Counteract Overheating in Urban Historical Areas in Rome
}

\author{
Flavia Laureti *, Letizia Martinelli and Alessandra Battisti ${ }^{\text {(D) }}$ \\ Department of Planning, Design and Technology of Architecture, La Sapienza University, Via Flaminia 72, \\ 00196 Rome, Italy; letizia.martinelli@gmail.com (L.M.); alessandra.battisti@uniroma1.it (A.B.) \\ * Correspondence: flavia.laureti@gmail.com; Tel.: +39-329-9666516
}

Received: 24 January 2018; Accepted: 14 March 2018; Published: 18 March 2018

\begin{abstract}
As urban overheating is increasing, there is a strong public interest towards mitigation strategies to enhance comfortable urban spaces, for their role in supporting urban metabolism and social life. The study presents an assessment of the existing thermal comfort and usage of San Silvestro Square in Rome during the summer, and performs the simulation of cooling strategies scenarios, to understand their mitigation potential for renovation projects. The first stage concerns a field analysis of the thermal and radiative environment on the 1st and 2nd of August 2014, including meteorological measurements and unobtrusive observations, to understand how people experience and respond to extreme microclimate conditions. In the second stage, the research proposes scenario simulations on the same day to examine the influence of cool colored materials, trees and vegetative surfaces on thermal comfort. The thermal comfort assessment was based on Physiologically Equivalent Temperature (PET), whereas microclimatic simulations were conducted with CFD calculations (ENVImet v.4.3.1). The first stage shows a strong relationship between lower PET values and attendance rate, depending on daily shading patterns. The second stage shows a relevant improvement of thermal comfort, with PET values of $-12{ }^{\circ} \mathrm{C}$ comparing to the no-intervention scenario, associated with a combination of cool materials and trees.
\end{abstract}

Keywords: overheating; summer heat stress; urban open space; shading; thermal comfort; Physiologically Equivalent Temperature; mitigation strategies; cooling technologies; cool materials

\section{Introduction}

There is strong public interest towards the sustainable and environmental regeneration of urban open spaces, particularly in the light of the increasing urban overheating phenomena due to multiple factors, among which the most relevant are: loss of green spaces, impervious paving surfaces, materials' characteristics of the built environment, combined with a very high increase of released anthropogenic heat $[1,2]$. The expression "urban open space" has been used largely and in many different thematic areas: architects and urban planners refer to it from a spatial perspective as all the outdoor areas of cities that are physically accessible to the public with few restrictions, that compromises several activities, planned or spontaneous, promoting the interaction of citizens and their feeling of identity and security, and ultimately improving indirectly local economy and people's health [3,4]. As stated by Katzschner [5], it is acknowledged that urban open spaces can contribute consistently to the quality of life within cities or contrarily enhance isolation and social exclusion [6], depending on the thermo-physical as well as social environment [7]. Thus, a good urban open space must address not only the "imageability" and aesthetic value of the city [8,9], but also support the daily activities and sociability of citizens and therefore it should represent a comfortable and livable place $[4,10]$. Its environmental quality and success depends on outdoor thermal comfort and microclimate, as stated by Gehl [10]: «few topics have greater relevance for comfort and well-being in city space than the 
actual climate where one is sitting, walking or biking» (p.168). Responses to microclimate may be unconscious, but they often result in a different use of open space in different climatic conditions [11].

Regarding thermal comfort, ASHRAE 55 defines it as «that condition of mind that expresses satisfaction with the thermal environment and is assessed by subjective evaluation» [12]. Thus, human thermal comfort is both physical and perceptual, it comprises interactions with the local microclimate, as well as physiological and psychological mechanisms [13]. Outdoor, these mechanisms mainly depend on four factors, variable in quantity, distribution and duration: air temperature $\left(T_{a}\right)$, air velocity $(v)$, vapor pressure $(V P)$ and Mean Radiant Temperature $\left(T_{m r t}\right)$, which parameterizes the impact of all short- and long-wave radiation fluxes on human body [14] and has a paramount daily impact [15]. Within the vertical scale of Urban Canopy Layer (UCL), which constitutes the lower part of the roughness sub-level, approximately from the ground to the rooftops of buildings, the effect of urban design on microclimate factors becomes substantial and it strongly affects thermal comfort [16], with the most relevant parameters being: topography, urban morphology, soil structure, the paving surfaces and the building materials [17], comprehending vegetated surfaces, green spaces and "cool sinks" [18], such as the ground and water $[19,20]$.

The high density of buildings and urban structures, the use of urban materials with low albedo, that is the ratio of global radiation reflected to the global radiation received by a surface [21], the lack of green spaces and pervious surfaces and the anthropogenic heat contribute to the general higher temperatures measured within the built environment comparing to the relatively cooler suburban and rural surroundings [22]. Unlike what happens in many rural areas, where plant cover and evaporation of soil moisture may moderate the increase of surface temperature that occurs when solar radiation is absorbed by the earth, a large proportion of urban areas consists of dry impervious surfaces, such as pavement and buildings, absorbing a great amount of solar radiation (short wave) and releasing it into the urban atmosphere in the thermal infrared (long wave) of the electromagnetic radiation spectrum. If we consider the historical city centre of Rome, in particular the area surrounding the present case study, the rate between built environment and green areas is around $70 \%$. The temperature of these surfaces, after receiving the solar infrared radiation, gets warmer than that of the overlying near-surface air, resulting in a sensible heat flux directed upward leading to an increase in the UCL air temperature. The phenomenon, known as Urban Heat Island (UHI), occurs chiefly during night-time [23], contributes significantly to the urban overheating phenomenon and it worsen the impact of climate change within cities because it intensifies energy consumption, deteriorates comfort conditions, put in danger vulnerable populations and amplify pollution problems [18,24-26]. To counteract these effects, many different solutions have been investigated and studied, among which the most significant ones are the mitigation strategies. Mitigation strategies aim to reduce greenhouse gas sources and emissions and prevent urban overheating [27], applied on the local scale, mitigation techniques aim to balance the thermal budget of cities by increasing thermal losses and decreasing the corresponding gains [18]. Effective mitigating approaches are the increase of vegetated surfaces and green spaces and the raise of urban materials' albedo, that is the reflection coefficient, measured from 0 , for a blackbody theoretically absorbing $100 \%$ of the incident solar radiation, to 1 corresponding to a total white surface, an ideal reflective surface [28].

Regarding the first class of mitigation strategies, vegetated surfaces and green spaces lower the dry-bulb air temperatures and increase latent cooling through evapotranspiration processes, which are the sum of evaporation and plant transpiration [29-31]. In addition, vertical elements such as trees also reduce direct solar radiation by shading, depending on the shape, dimension, Leaf Area Density (LAD) of the single plant, which is defined as the portion of leaf surface in $\mathrm{m}^{2}$ within a $\mathrm{m}^{3}$ of air, and Leaf Area Index (LAI) which is defined as a dimensionless value of the leaf area per unit of ground area. If we consider the interaction between solar radiation and a tree during summer, between $10 \%$ and $30 \%$ of solar radiation generally reaches the base of a tree [32]. Thus, types, sizes and arrangements of leaves play an important role in improving efficiency in radiation absorption and reflection. The most used greening techniques include: green pavements, ranging from traditional green lawn to the hybrid 
permeable pavements characterized by tiles mixed with greenery (i.e. grass pavers); trees, vertical greening and green roofs.

As underlined by Upreti et al. [33] and Saaroni et al. [34] urban trees represent a feasible and advantageous form of green infrastractures for mitigating urban overheating and in addition to their microclimate benefits, trees present other benefits ranging from social (e.g., enhancing quality of urban life), economic (e.g., increase of property value), health (e.g., air quality improvement, reducing stress, improving physical health), visual (e.g., creating seasonal interest by highlighting seasonal changes) and aesthetic (e.g., improving scenic quality) advantages to humans. Whereas, the problems and hazards associated to the extensive use of trees within cities are related to a reduction of the solar access and wind speed, carbon pollution through landscape and tree management practices, maintenance problems and pollen diffusion, as underlined by Roy et al. who [35] conducted a systematic quantitative review of urban tree benefits, costs and assessment methods across cities in different climatic zones.

Regarding their mitigation potential, Shashua et al. have investigated the effect of trees and cool pavements on urban streets in Athens during hot summer conditions [36]. Among the different findings, they highlight how the effect of trees represents the dominant factor affecting comfort, since the increase in vegetation street coverage from $8 \%$ to $50 \%$ leads to a $T_{m r t}$ value decrease of $13.6 \mathrm{~K}$ and to a PET value decrease about $8.3 \mathrm{~K}$ at noontime. As stated by the authors, «the tree option is the most beneficial agent in improving the microclimate, as well as the comfort situation». Another study conducted by Ketterer and Matzarakis in Stuttgart [37] underlines how the maximal value of PET over a green unshaded area is $35^{\circ} \mathrm{C}$, whereas it can exceed $58{ }^{\circ} \mathrm{C}$ over a sealed and asphaltic surface. The authors also suggest that a green surface can reduce PET by up to $7 \mathrm{~K}$ in the neighboring streets and areas, especially on the lee side, thus helping to establish an «ideal urban climate» [38]. In another recent study conducted by Cheung and Jim [39] the cooling effects of a tree and a concrete shelter have been compared using PET and UTCI. The research underlines how the cooling effect related to a tree shade was significant but nevertheless higher than the one provided by the concrete artificial shading. In fact, as stated by the authors, the mean daytime cooling effects generated by the tree were $0.6{ }^{\circ} \mathrm{C}$ (air temperature), $3.9^{\circ} \mathrm{C}$ (PET) and $2.5^{\circ} \mathrm{C}$ (UTCI), which were higher than the shelter at $0.2{ }^{\circ} \mathrm{C}, 3.8^{\circ} \mathrm{C}$ and $2.0^{\circ} \mathrm{C}$ respectively. Nevertheless, in order to inform the urban designers and planners on the strategic use of natural and artificial shading devices, an overview of the general benefits provided by the green infrastructure solutions, such as trees in this case, must be done as exposed in the aforementioned researches.

Regarding the second class of mitigation techniques called "cool materials", the present study focuses on specific innovative materials presenting a high solar reflectance and high thermal emittance compared to traditional ones, which results in a lower surface temperature, thus the name "cool materials", affecting the radiative environment and $T_{m r t}$. At building scale, this means that the heat penetrating into the building decreases, whereas at city scale this contributes to decreased air temperatures as the heat transfer from warmer surfaces is lower [40].

Nowadays, the cool materials class comprises: the first generation, including natural materials with high reflectivity [41], the second generation, based on the development of artificial white materials design to have a high albedo equal or higher than 0.85 [42]. These first high-reflective materials, known traditionally as cool materials, presented visibility problems for the reflected UV radiation toward the pedestrian; therefore, they lead to the development of the third generation of cool materials, known as "cool colored materials", comprehending colored high reflective materials that present a high reflectivity in the infrared spectrum of solar radiation (NIR) [43], thus appearing like traditional dark materials but with low surface temperature, and finally the fourth generation, based on nanotechnological additives like thermochromic paints [44] or PCM (phase change materials) doped cool materials [45]. Moreover, recent studies are now focusing on the advances of cool colored coatings to be applied both on roof and on building façades in historic context, due to their appearance similar to the traditional colors of the consolidated city. Among these cool coatings, a recent interest has 
emerged towards mineral-based coatings that present a similar behavior to high-reflective materials, as demonstrated by Kolokotsa (2012) [42], and directionally reflective materials, these materials present multifaceted surfaces whose color and reflectance change accordingly to the surface orientation and the direction of incident solar radiation, reflecting sunlight during the summer and absorbing light during winter [46].

The interest towards these type of cooling measures related to the built surfaces, depends on the massive presence of roofs and pavements representing a major part of the urban fabric: in fact, roofing surfaces correspond to about $20-40 \%$ of the total area exposed to solar radiation and pavements amount approximately to $29-44 \%$ of the total urban ground [47], thus their implementation could be massively handled with promising local and global benefits energy and environmental benefits [48,49].

There is significant body of research on cool materials and coatings, among which Santamouris et al. [50], Santamouris [18] and Pisello [49] offer a consistent review of the main cool materials and coatings, investigated in laboratory or on field, developed firstly for pavements and roofs and then for building façades. In particular, regarding the benefits related to the cool coatings class, as stated by Pisello [49], when applied over roof and wall, they provide a very effective solution for passive cooling of buildings indoors and of local outdoor microclimate. Studies conducted on different cities, such as New York (USA), Los Angeles (USA), Athens (Greece), show that the expected mean decrease of the average ambient temperature is close to $0.3 \mathrm{~K}$ per 0.1 rise of the albedo, while the corresponding average decrease of the peak ambient temperature is close to $0.9 \mathrm{~K}$ [18]. Regarding the effect of cool roof on the city scale, a study on 14 cool reflective coatings, selected from the international market [51], demonstrated that the use of reflective coatings can reduce a white concrete tiles surface temperature under hot summer conditions by $4{ }^{\circ} \mathrm{C}$ and during the night by $2{ }^{\circ} \mathrm{C}$.

Although cool materials can be applied for both pavements, roof and façade surfaces, the development of cool pavements for outdoor spaces has remained at laboratory test level, only recently they have been applied in outdoor spaces [52]. In fact, pavements' thermal behavior is affected by convection due to traffic movement and by shadings due to people, traffic and urban structures, and a pavement's coat is subject to rapid dirtying and wearing. However, in the last decades, cool pavements have been developed and analyzed following the same principles used for the researches on cool roofs $[21,53,54]$. One of the first and relevant field measurement regarding cool pavements, conducted in Flisvos urban park in the greater Athens area, shows that extensive application of reflective pavements may reduce the peak daily ambient temperature during a typical summer day up to $1.9^{\circ} \mathrm{C}$, while surface temperatures were reduced up to $12^{\circ} \mathrm{C}$ [52]. Regarding the mitigation potential of surface temperature values, a study of Kinouchi [55] conducted in Japan in 2003, highlighted the lower Ts values of cool pavements. The study considers the application on an asphalt road of a cool colored coating, with low reflectivity in the visible part of sunlight spectrum $(23 \%)$ and high reflectivity of near infra-red (87\%). The cool colored coating was applied over two sample of street pavement in two different sites, respectively in Tsukuba and in Okinawa, and resulted in an average surface temperature of $15^{\circ} \mathrm{C}$ lower than a conventional asphalt pavement.

Most of the researches on cool materials have been focusing on their mitigation potential towards ambient air temperatures, surface temperatures or mean radiant temperatures. A recent study conducted by Piselli et al. [56] highlights the different benefits related to cool pavements and trees, in terms not only $T_{a}, T_{s}$ but also of comfort (PET) by means of in situ monitoring campaigns, questionnaires to the moving pedestrians, and microclimate simulations. From the analysis and comparison of the air temperature, $T_{m r t}$ and PET values among the five scenarios object of study, the most beneficial scenarios were the one which comprised an overall upgrade of the green and trees areas (scenario 2) and the mixed scenario (scenario 5) which included a combination of cool pavements, trees and photovoltaic pavement. Regarding this last scenario, the air temperature at 12:00 was found to be $1{ }^{\circ} \mathrm{C}$ lower than the initial condition, the $T_{m r t}$ was found to be about $20{ }^{\circ} \mathrm{C}$ lower and the related comfort conditions were improved up to $15^{\circ} \mathrm{C}$, underlying not only an effective mitigation potential 
of cool pavements but also a good performance regarding its effects on thermal comfort when coupled with green technologies.

Nevertheless, as aforementioned, until recently the majority of existing studies concentrated mainly on the reduction of surface temperature and air temperature, which depends on the spatial scale of the area in question [31,37] or on the related energy saving for indoor spaces, neglecting the general effect of cool materials on outdoor thermal comfort through its influence on $T_{m r t}$. However, as the human body is non-selective in its absorption of solar energy, the effect of albedo modification on thermal sensation may actually increase thermal stress in warm environments [57]. Regarding this aspect, Chatzidimitriou and Yannas [58] verified that lower surface temperatures, by use of reflective materials, does not compensate for the higher amounts of reflected solar radiation released in the urban environment and directly effecting the thermal comfort of the pedestrian.

Therefore, given the relevance of these technologies in counteracting UHI and in mitigating overheating, the present research aims to assess the effect of urban greenery and cool colored materials, in different combinations on outdoor thermal comfort. It also presents a different perspective for the renovation of historical urban squares, attentive to the microclimatic effect of urban morphology and materials and based on field analysis of existing thermal comfort conditions and visitors' consequent behavior. Mediterranean historical city centers are often characterized by a minimal use of greenery, since they are often perceived as paved space; conversely, the proposed approach goes beyond the typical example of Mediterranean paved "placas duras" [3], incorporating urban greenery and cool colored materials as minimal strategies to upgrade the sustainability of historical urban open spaces, while still maintaining the image of the city in the preservation of its traditional color patterns.

Following this assumption, the current study:

1. analyzes the existing relationship between attendance, shading patterns depending on urban morphology and thermal comfort in a public square in the Mediterranean climate during overheating periods [3];

2. evaluates the effects on outdoor thermal comfort of renovation scenarios of the square, defined according to the field analysis and based on urban greenery and cool colored materials, single or combined;

3. compares the thermal comfort conditions of different points of the square, corresponding to different morphological and material conditions, for the renovation scenarios.

\section{Materials and Methods}

\subsection{Case Study: Site Location and Microclimatic Characteristics}

The study was carried out on San Silvestro square (Figure 1), a square located in the historic city center of Rome (coordinates $41^{\circ} 54^{\prime} \mathrm{N} 12^{\circ} 30^{\prime} \mathrm{E}$, elevation $20 \mathrm{~m}$ ), the capital of Italy and its largest and most populated city. The principal river, the Tiber, branches through the core of the city north to south and the center of the city is about $24 \mathrm{~km}$ from the Mediterranean Sea; its climate is dry-subtropic Csa, according to Köppen-Geigen classification [59].

The square was selected for its social and cultural relevance and for its location, since it is near one of the main street of the historic centre (Via del Corso), close to relevant tourist attractions, shopping boulevards and offices and the related public transport hub. The square is a quadrangular paved open space measuring approximately $80 \times 60 \mathrm{~m}^{2}$ and has undergone a renovation in 2011, proposing a complete pedestrianization of the square for recreational use, furnishing it with long, marble benches. The renovation divided the area in two different squares: one on the West side with the benches outlining a rectangular area, and the other one, wider, located in the centre-East of the square and characterized by benches following an elliptical pattern.

Even though the initial design proposed an integration of trees and green lawn, as well as the insertion of a fountain in the elliptical square, the final construction didn't include those elements and proved to have no concerns for the microclimatic conditions and the thermal behavior of the place. 


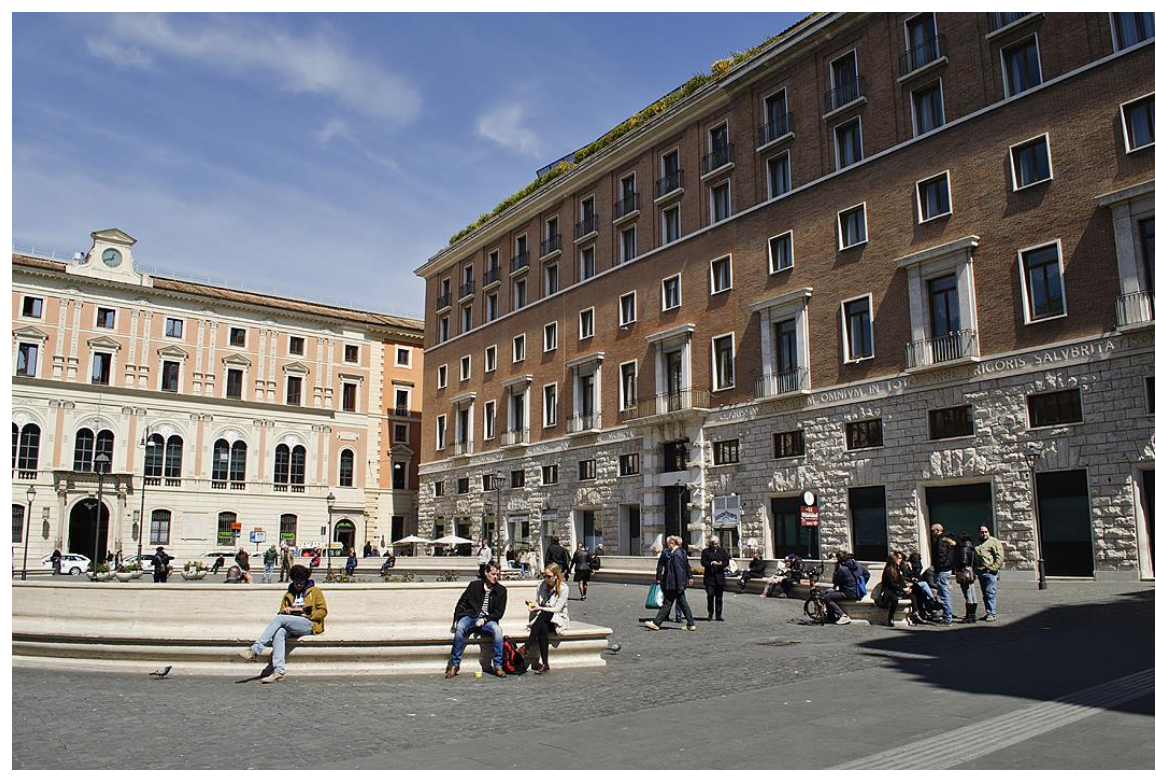

Figure 1. A picture of san Silvestro square taken in March 2015 (this is the reason for many visitors lingering on the sunny benches).

The surrounding buildings, representing the urban interface of the open space and its main interacting surfaces, are about $4-5$ floor height, with a height/width ratio $(\mathrm{H} / \mathrm{W})$ equal to 0.36 . Thus, the square does not offer a natural or shaded environment other than the buildings' shade.

In addition, it must be underlined that San Silvestro square has been selected in this study because it represents a typical urban open space of the historic tissue of Rome for its dimensions, the morphology of the surrounding buildings, the relation between its sides and especially for the height and width ratio ( $\mathrm{H} / \mathrm{W}=0.30 \mathrm{ca}$.). In fact, if we consider the evolution of the urban open space in the historic centre of Rome, San Silvestro square recalls the Centuratio from the ancient Roman period, that is to say the quadrangular open space resulting from the Cardo and Decumanus grid system, which measured about $70 \mathrm{~m}$ per side and the typical height of the surroundings Insulae which were about $20 \mathrm{~m}$, resulting in a $\mathrm{H} / \mathrm{W}$ ratio of about 0.3 . Similar proportions remain through the urban planning evolution of the historical tissues in Rome, and are visible in other historical squares such as the Immacolata square (beginning of the 20th century) in the San Lorenzo neighbourhood which presents a H/W ratio of $0.35 \mathrm{ca}$. or Madonna dei Monti square (Renaissance period) in the Monti neighbourhood which presents a $\mathrm{H} / \mathrm{W}$ ratio of $0.4 \mathrm{ca}$.

\subsection{Field Data Collection and Meteorological Measurements}

The first stage of the study involved a field collection of meteorological data and unobtrusive observations of the visitors of the square, acquired on Friday 1 and Saturday 2 August 2014, to explore people behavior and usage of the square on work days and on the weekend, each $10 \mathrm{~min}$ from 8:00 to 20:00 [3]. The observations recorded the people lingering or sitting for more than $10 \mathrm{~min}$, omitting passersby and separating the people in shaded or unshaded locations.

Following the definition given by Kántor and Unger [32], data about the number of visitors every $10 \mathrm{~min}$ are referred to as momentary attendance. Visitors' behavior depends on local time during summer, so all results refer to Local Standard Time (LST) +1 .

Air temperature and relative humidity was measured using a humidity Temperature Meter, $\mathrm{HH} 314 \mathrm{~A}$, with a measurement resolution of $0.1 \mathrm{~K}$ and $0.1 \%$, with an accuracy of $2.5 \%$ for relative humidity and $0.7 \mathrm{~K}$ for air temperature.

The instrument was mounted on a lightweight aluminum tripod camera stands at a height of $1.1 \mathrm{~m}$, corresponding to the average height of the gravity centre of adults [60], and was positioned in an 
open point (point A on Figure 2) and sheltered from direct solar radiation, as recommended by Oke [16]. The Collegio Romano meteorological station, situated approximately $500 \mathrm{~m}$ from San Silvestro square, provided data for air velocity with $10 \mathrm{~min}$ resolution and for cloud cover $(c c)$. Since the station is above roof level (40 $\mathrm{m}$ above ground), air velocity was reduced to the reference height of $1.1 \mathrm{~m}$ :

$$
\begin{aligned}
& v_{1.1}=v_{h} \cdot\left(\frac{1.1}{h}\right)^{\alpha}, \\
& \alpha=0.12 \cdot z_{0}+0.18,
\end{aligned}
$$

where $v_{1.1}$ is the air velocity at $1.1 \mathrm{~m}$ height, $v_{h}$ is the air velocity at the meteorological station's height, $h$ is the meteorological station's height, $\alpha$ is an empirical exponent depending on the surface roughness and $z_{0}$ is the roughness length. In this study, $z_{0}$ was set at $1.5 \mathrm{~m}$, which represents a densely built-up urban area (high floor area ratio) according to the classification of Davenport [61] and several studies on thermal comfort in urban environments $[37,62,63]$. Finally, the Mean Radiant Temperature $\left(T_{m r t}\right)$ has been calculated throughout the day using the Rayman software [15], by importing cloud cover, time of year and surrounding obstacles.
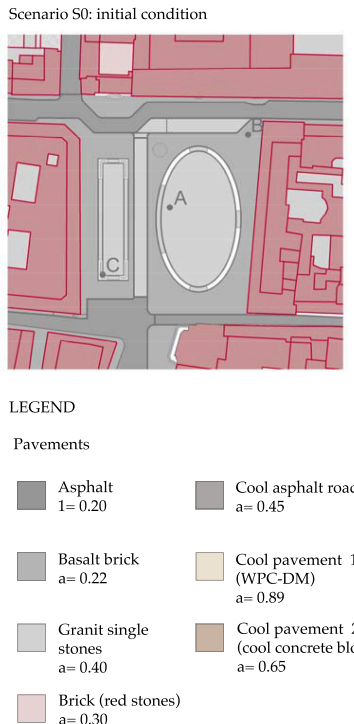

Brick
$\mathrm{a}=0.30$
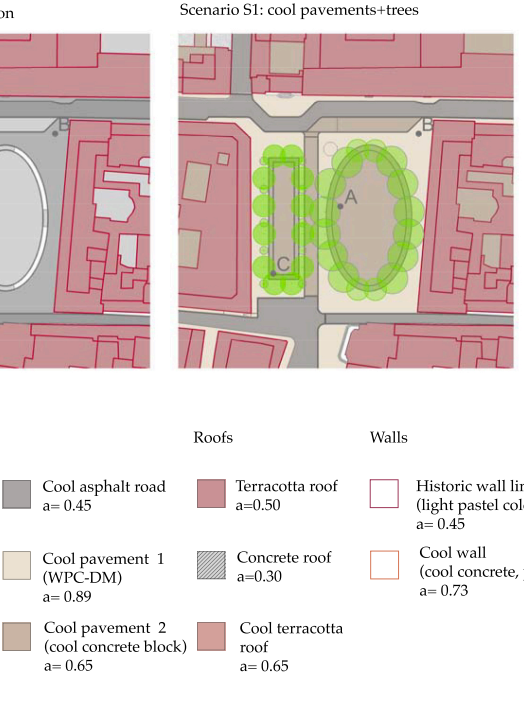

oofs
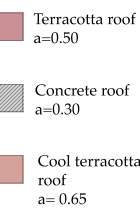

$\mathrm{a}=0.65$

Figure 2. Initial condition scenario S0 (a), first renovation scenario S1 (b), second renovation scenario S2 (c). Point A, B and C represent the selected location for the comparisons among the scenarios.

The microclimate parameters measured and collected in the first stage analysis, on the first day (Friday 1 August 2014), are used as input data for the microclimate simulations of the renovation scenarios in ENVI-met, modelled and analyzed in the second stage of the study.

\subsection{Scenario Simulation Definition}

The second stage of study focuses on the simulation and comparison of two different renovation scenarios applied to the square, involving the use of cool materials for pavements, façades and roofs and the use of greenery. Each scenario has been compared to the initial condition used as a test reference model (S0) to assess the renovation strategies performance.

The percentage and distribution of applied materials depends on morphological and typological limitations of the area. In particular, the artificial materials were selected and applied in order to satisfy the following criteria: 
1. to present the higher possible non-specular reflectivity to solar radiation for each surfaces' common range,

2. to present the highest possible emissivity factor,

3. to present the highest possible aesthetic value and integration within the image of the historical context.

The natural materials and elements such as grass and trees, were selected in order to satisfy the following criteria:

1. for the trees to present a medium-high Leaf Area Density (LAD),

2. to be applicable and in compliance within the Mediterranean context and traditional urban greenery of the city.

Moreover, the position of greenery is based on the results of the field analysis of the first stage of the study, which indicates a correspondence between shading patterns and attendance of sitting places.

The first renovation scenario (S1) focuses on the minimal intervention and on the principal surfaces interacting with the pedestrian level: the urban pavement. It aims to analyze the combined cooling effect of trees and cool pavements and their related outdoor comfort. The second renovation scenario (S2) focuses on the combination of different materials, applying cool colored materials on roofs and walls and increasing trees and the vegetated surfaces of urban pavements.

Figure 2 represents the initial condition scenario S0 (initial condition) and the two renovation scenarios S1 (cool pavements + trees) and S2 (cool roofs + cool walls + trees + grass), with the specific renovation strategies. There are different institutions and organizations that are creating and implementing their digital database of cool materials, such as the Energy Star Roof Products, the Lawrence Berkley Institute, the US Cool Roof Rating Council and the EU Project Cool Roofs [50]. In this study, the cool materials were selected from two studies carried out by Santamouris et al. and Gobakis et al. [50,64].

Table 1 summarizes the materials database used in the initial scenario, S0; in the first renovation scenario S1 (cool pavements + trees) and in the second renovation scenario S2 (cool roofs + cool walls + trees + grass); whereas Table 2 summarizes the albedo and LAD coefficients of the tree' species modelled in ENVI-met V.4.3.1.

\subsection{Thermal Comfort Analysis}

The thermal comfort analysis is based on PET (Physiological Equivalent Temperature) index, defined as the equivalent temperature at any given place (outdoors or indoors) to the air temperature at which, in a typical indoor setting, the heat balance of the human body, with light activity $(80 \mathrm{~W})$ and heat resistance of clothing of 0.9 clo, is maintained with equal core and skin temperatures to those under the conditions being assessed [65].

The PET index belongs to a set of detailed thermal indices based on the human energy balance which, as underlined by Matzarakis et al. [66], give us information on the effects of complex thermal environments on humans, taking into account the human thermoregulatory mechanisms and the human circulatory system like the constriction or dilation of peripheral blood vessels and the physiological sweat rate, in order to produce a comprehensive, reliable representation of human body's actual physiological sensations [3]. As a thermal index, PET requires basic meteorological input parameters: air temperature, air humidity, wind speed, short and long wave radiation fluxes and in order to calculate the human energy balance, thermo-physiological parameters, such as heat resistance of clothing (clo) and activity of humans (in $\mathrm{W}$ ), are required. The following assumptions are made for the indoor reference climate: $T_{m r t}=T_{a} ; v=0.1 \mathrm{~ms}^{-1} ; V P=12 \mathrm{hPa}$. PET depends on four main physical parameters, which characterize the thermal environment: air temperature $\left(T_{a}\right)$, water vapor pressure $(V P)$, air velocity $(v)$ and Mean Radiant Temperature $\left(T_{m r t}\right)$. 
Table 1. Materials' database of the analyzed scenarios: S0 initial condition, S1 first renovation scenario (cool pavements + trees), second renovation scenario (cool roofs + cool walls + trees + grass) .

\begin{tabular}{|c|c|c|c|c|c|c|}
\hline \multirow[b]{2}{*}{ Surface } & \multicolumn{2}{|l|}{ So } & \multicolumn{2}{|l|}{ S1 } & \multicolumn{2}{|l|}{ S2 } \\
\hline & Name & Albedo (a) & Name & Albedo (a) & Name & Albedo (a) \\
\hline \multirow[t]{2}{*}{ Roofs } & $\begin{array}{c}\text { clay tiles } \\
\left({ }^{*} \text { terracotta roof }\right)\end{array}$ & 0.50 & $\begin{array}{c}\text { clay tiles } \\
\left({ }^{*} \text { terracotta roof }\right)\end{array}$ & 0.50 & \multirow{2}{*}{$\begin{array}{c}\text { cool red brick tiles } \\
\left({ }^{*} \text { cool terracotta roof }\right)\end{array}$} & \multirow[t]{2}{*}{0.65} \\
\hline & concrete tiles & 0.30 & concrete tiles & 0.30 & & \\
\hline Walls & $\begin{array}{c}\text { areated brick block with } \\
\text { lime plaster } \\
\left({ }^{*} \text { historical wall }\right)\end{array}$ & 0.45 & $\begin{array}{c}\text { areated brick block with } \\
\text { lime plaster } \\
\left({ }^{*} \text { historical wall }\right)\end{array}$ & 0.45 & $\begin{array}{c}\text { yellow cool coating } \\
\text { with } \mathrm{TiO}_{2} \\
\left({ }^{*} \text { cool wall }\right)\end{array}$ & 0.73 \\
\hline \multirow{3}{*}{ Pavements } & asphalt & 0.20 & $\begin{array}{l}\text { cool colored thin } \\
\text { layer asphalt }\end{array}$ & 0.45 & asphalt & 0.20 \\
\hline & basalt tiles & 0.22 & $\begin{array}{l}\text { white Portland cement with } \\
\text { dolomitic marbles plaster }\end{array}$ & 0.89 & basalt tiles & 0.22 \\
\hline & flint blocks & 0.40 & $\begin{array}{l}\text { cool colored pigmented } \\
\text { concrete tiles }\end{array}$ & 0.65 & flint blocks & 0.40 \\
\hline \multirow{4}{*}{ Greenery } & \multirow{4}{*}{---} & \multirow{4}{*}{---} & Citrus $x$ aurantium (deciduous) & 0.40 & $\begin{array}{l}\text { Citrus } x \text { aurantium } \\
\text { (deciduous) }\end{array}$ & 0.40 \\
\hline & & & $\begin{array}{l}\text { Albizia julibrissin } \\
\text { (deciduous) }\end{array}$ & 0.70 & $\begin{array}{l}\text { Albizia julibrissin } \\
\text { (deciduous) }\end{array}$ & 0.70 \\
\hline & & & \multirow{2}{*}{$\begin{array}{l}\text { Koelreuteria paniculata } \\
\text { (deciduous) }\end{array}$} & \multirow{2}{*}{0.60} & $\begin{array}{l}\text { Koelreuteria paniculata } \\
\text { (deciduous) }\end{array}$ & 0.60 \\
\hline & & & & & $\begin{array}{l}\text { Medicago sativa } \\
\text { (evergreen) }\end{array}$ & 0.20 \\
\hline
\end{tabular}

* abbreviated classification as illustrated in the plans' legend.

Table 2. Greenery characteristics.

\begin{tabular}{ccc}
\hline Name & Albedo (a) & Leaf Area Density (LAD) $\mathbf{~ m}^{2} / \mathbf{m}^{\mathbf{3}}$ \\
\hline Citrus $x$ aurantium (deciduous) & 0.40 & $0.50-0.60$ \\
Albizia julibrissin (deciduous) & 0.70 & $0.60-0.70$ \\
Koelreuteria paniculata (deciduous) & 0.60 & $0.70-0.80$ \\
\hline
\end{tabular}


Regarding the current study, the PET index has been selected among other thermal indexes, because of its extensive application to analyze thermal comfort in different climates [67-69] and its measurement unit $\left({ }^{\circ} \mathrm{C}\right)$, making the results easy to understand for urban planners or decision makers, who are generally not so familiar with modern human biometereological terminology [70]. However, similarly to other thermal indices, the PET shows some limitations in its applicability as underlined by Chen and Matzarakis [71]: in particular variations in air humidity and clothing insulation show weak influence on PET. Nevertheless, for the aforementioned characteristics, specifically for the extensive scientific literature and because it has been used in urban built-up area with complex shading patterns and generated accurate predictions of thermal environments [72] the PET index was selected as the primary thermal index in this study.

The main focus of the second stage of the study is to assess the impact of combination of tree density, green surfaces and albedo of materials; therefore plant, surface and air interaction are essential. Micro-scale model ENVI-met v.4.3.1 [73,74] was selected to analyze the human-biometeorological conditions and their changes due to the renovation scenarios, as the software calculates micro-scale surface-air-plant interactions in a three-dimensional non-hydrostatic way. In the latest updated version (28 November 2017) solar radiation analyses, vegetation modeling, advanced plant simulation, detailed building physics and air pollution are included. It is also possible to assess the energy budget at ground surfaces and to visualize the surface temperatures in 3D mode on roofs, walls as well as pavements. Therefore, its spatial and temporal resolution provides a good basis for the quantification of changes and microclimatic interactions in the urban environment.

We approximated the scenario solutions in terms of spatial configurations within the specific constraints of the software, thus:

1. the grid cell dimension used for the ENVI-met models measures $2 \mathrm{~m} \times 2 \mathrm{~m}$, in order to optimize the time needed for the calculation as well as to maintain a proper level of detail;

2. walls and roofs were modelled in the Database Manager specifying their three characteristic layers, in order to take into account, the thermal characteristic of the surrounding building volumes;

3. for the characterization of the exterior layer of walls and roofs, in order to balance the uncertain application of materials in 3Dmode within the ENVI-met SPACE and to approximate the real conditions of building materials, we chose to apply the prevalent material, that is clay tiles for the roofs and aerated brick block with lime plaster for the walls.

The ENVI-met simulations were carried out from 8:00 to 20:00 of 1st August 2014, plus a stabilizing period. The input data used in ENVI-met derived from the measurements and calculations made during the first stage of the study, specifically they include: air temperature $\left(T_{a}\right)$ and relative humidity $(\mathrm{RH})$ measured at San Silvestro square, air velocity $(v)$ and cloud cover $(c c)$ from the Collegio Romano meteorological station. In order to calculate PET, we used the ENVImet package's PET index calculator BioMet. As for the thermo-physiological parameter of the human body, we assumed a "typical European male" (35 years old, $1.75 \mathrm{~m}$ tall, weight $75 \mathrm{~kg}$ ), with a clothing index of 0.6 clo (corresponding to a summer business suit) and an activity rate of $80 \mathrm{~W}$.

\section{Results}

The following data represent the average value between the two days of analysis conducted in San Silvestro square, on the 1st and 2nd of August 2014.

During the day of analysis in the 1st stage of the study, the minimum value of air temperature of $22.6^{\circ} \mathrm{C}$ was recorded at 8:00, while the maximum value of $32.1^{\circ} \mathrm{C}$ occurred at 13:00. The average air temperature in daytime was $29.2^{\circ} \mathrm{C}$. The minimum value of water vapor pressure of $19.9 \mathrm{hPa}$ was reached at 18:10, while the maximum value was $25.9 \mathrm{hPa}$ at 9:20 and 9:40. The average of water vapor pressure was $23.1 \mathrm{hPa}$. Table 3 shows a systematic overview of the principal meteorological parameters measured in the square, in particular: air temperature $\left(T_{a}\right)$, air velocity $(v)$ relative humidity $(\mathrm{RH})$ and 
cloud cover $(c c)$, and finally the Mean Radiant Temperature $\left(T_{m r t}\right)$ calculated with Rayman on the 1 August 2014, from 8:00 to 19:00.

Table 3. Summary of the meteorological parameters measured in the square and collected from the Collegio Romano meteorological station on the 1st and 2nd of August 2014: air temperature $\left(T_{a}\right)$, air velocity $(v)$, relative humidity $(\mathrm{RH})$ and cloud cover $(c c)$, and the Mean Radiant Temperature $\left(T_{m r t}\right)$ calculated with the Rayman software.

\begin{tabular}{lcccccc}
\hline \multicolumn{1}{c}{ Day } & Hour & $\begin{array}{c}\text { Air } \\
\text { Temperature } \\
\left(\boldsymbol{T}_{\boldsymbol{a}}\right)\end{array}$ & $\begin{array}{c}\text { Relative } \\
\text { Humidity } \\
(\mathbf{R H})\end{array}$ & $\begin{array}{c}\text { Air Velocity } \\
(\boldsymbol{v})\end{array}$ & $\begin{array}{c}\text { Cloud Cover } \\
(\boldsymbol{c c})\end{array}$ & $\begin{array}{c}\text { Mean Radiant } \\
\text { Temperature } \\
\left(\boldsymbol{T}_{\boldsymbol{m r t}}\right)\end{array}$ \\
\hline 1 August 2014 & $08: 00$ & 22.6 & 77.2 & 0.4 & 0 & 23.6 \\
1 August 2014 & $09: 00$ & 24 & 73 & 0.4 & 0 & 25.2 \\
1 August 2014 & $10: 00$ & 25.7 & 65.2 & 0.8 & 0 & 27 \\
1 August 2014 & $11: 00$ & 28.6 & 58.9 & 0.4 & 0 & 44.2 \\
1 August 2014 & $12: 00$ & 30.2 & 53.4 & 0.4 & 1 & 48 \\
1 August 2014 & $13: 00$ & 32.1 & 47 & 0.8 & 1 & 40.2 \\
1 August 2014 & $14: 00$ & 30.6 & 55.8 & 0.8 & 1 & 41.7 \\
1 August 2014 & $15: 00$ & 30.3 & 55.4 & 1.2 & 1 & 43.4 \\
1 August 2014 & $16: 00$ & 30.9 & 51.5 & 2.5 & 1 & 42.6 \\
1 August 2014 & $17: 00$ & 30.4 & 53.8 & 1.7 & 1 & 32.8 \\
1 August 2014 & $18: 00$ & 29.1 & 57 & 2.1 & 1 & 39 \\
1 August 2014 & $19: 00$ & 29.8 & 60.5 & 1.7 & 1 & \\
\hline
\end{tabular}

\subsection{Relationship between Attendance, Shading Patterns and Thermal Comfort}

The first stage of the study analysed the relationship between the attendance of the square, daily shading patterns and thermal comfort conditions during the day. Shade in the square derives entirely from the surrounding buildings, therefore is higher during the morning and late afternoon, with a percentage of shaded area of $99 \%$ at 8:00 and $100 \%$ at 20:00 and decreases towards midday, when in reaches the minimum of $13 \%$ at $12: 00$ and $14: 00,7 \%$ at $13: 00$.

The majority of visitors concentrated in specific time periods (Figure 3), corresponding to the main usages of the square by workers of the nearby offices and tourists: early morning (8:00 to 9:00), presumably when the workers have breakfast or read newspapers at the square before going to work around 9:00; lunchtime (13:00 to 14:30) and late afternoon (17:00 to 19:00).

Momentary attendance in unshaded locations is significantly lower than in shaded locations: visitors massively preferred shaded locations, throughout the day, whenever possible. The momentary attendance in unshaded locations changed from 0-4 people during the morning from 8:00 to 11:00, to reach the peak of 9-8 people at 12:00-13:00, to lower again to 2-3 in the afternoon after 17:00. On the contrary, in shaded locations the number of visitors during the morning extended from 8-20 people at 10:00 to 11-25 at 11:00; then, it drastically lowered to $0-4$ people at 12:00 and $0-9$ at 13:00, to increase in the afternoon, reaching 52-94 at 18:00. The low attendance in shaded locations at 12:00 and 13:00 corresponds with the almost complete absence of sitting possibilities in shade, either formal on the benches or informal on building's steps or flowerpots. This preference is in accordance with thermal comfort analysis, as PET in shaded locations was consistently lower than PET in unshaded locations, due to the reduction of direct solar radiation [3].

The boxplot in Figure 4 divides the median momentary attendance into classes of PET values for four-time periods: it indicates that visitors generally preferred locations corresponding to PET below $35^{\circ} \mathrm{C}$, which coincided with shade. In the morning interval (from 8:00 to 10:50), PET of $26{ }^{\circ} \mathrm{C}-30{ }^{\circ} \mathrm{C}$ and PET of $30^{\circ} \mathrm{C}-35^{\circ} \mathrm{C}$ matched with the highest median of momentary attendance of 12 ; from 14:00 to 19:50, the highest median of momentary attendance reached 40 people for PET between $30^{\circ} \mathrm{C}$ and $35^{\circ} \mathrm{C}$, while in the late afternoon (from 17:00 to 19:50), the highest median of momentary attendance of 60 people corresponds to PET between $30^{\circ} \mathrm{C}$ and $35^{\circ} \mathrm{C}$. In the interval 11:00-13:50 there was an exception, with the highest median of attendance of 5.5 for PET between $35^{\circ} \mathrm{C}$ and $40{ }^{\circ} \mathrm{C}$; however, 
as depicted by Figure 3, during that time period there was the lowest percentage of shaded area and shaded sitting locations.

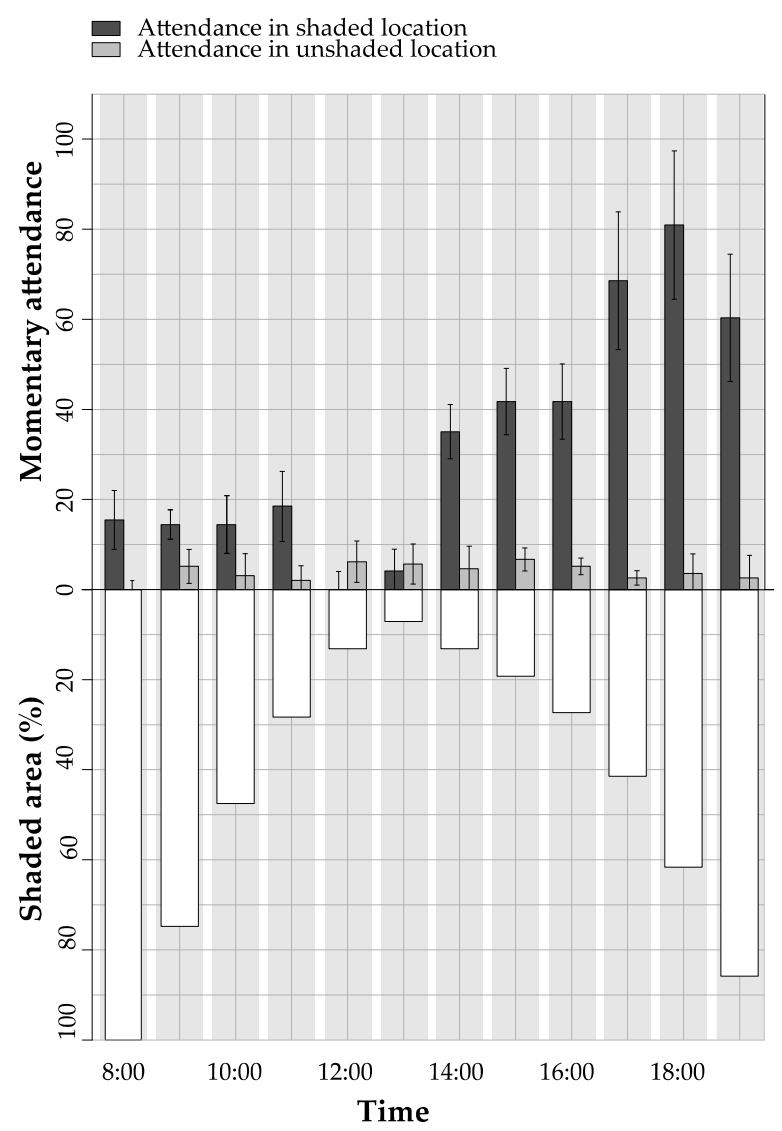

Figure 3. Hourly median and standard deviation of the attendance for shaded (dark grey) and unshaded (light grey) locations, on 1st and 2nd of August 2014, from 8:00 to 19:00, compared with the hourly percentage of shaded area (white bars) in San Silvestro Square [3].

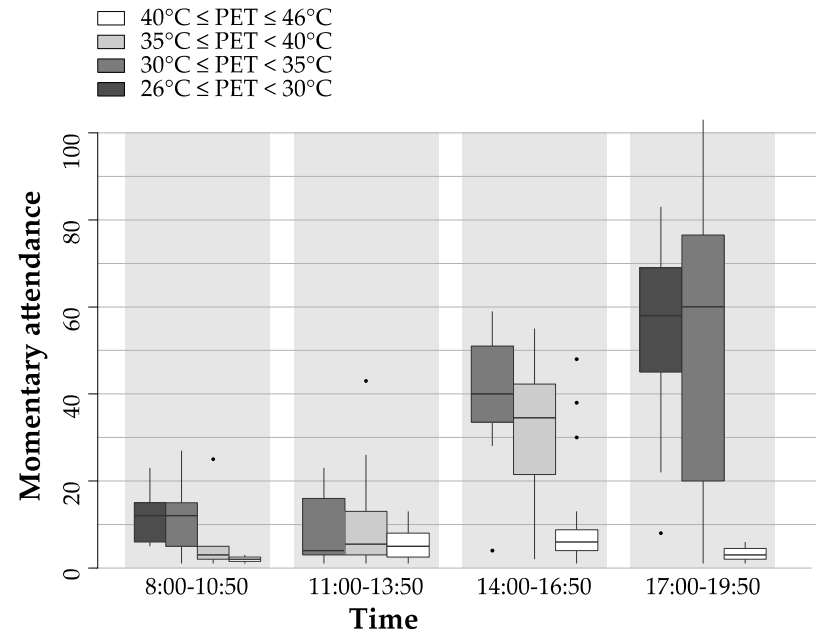

Figure 4. Attendance for classes of PET for four-time intervals during the day: morning (8:00, 10:50), midday (11:00, 13:50), afternoon (14:00, 16:50), late afternoon (17:00, 19:50) in San Silvestro Square [3]. 


\subsection{Spatial Analysis of Thermal Comfort Distribution for the Simulation Scenarios}

The second stage of the study compares the thermal comfort of the initial condition scenario S0 and the two renovation scenarios S1 and S2. Figure 5 shows the spatial distribution of PET values among the square for S0, S1 and S2 at three selected hours: 8:00, 13:00, 17:00, which corresponds to the highest attendance of the day, according to the observed momentary attendance shown in Figure 3.

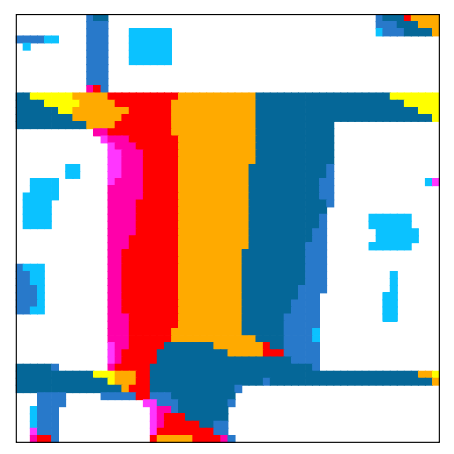

(a)

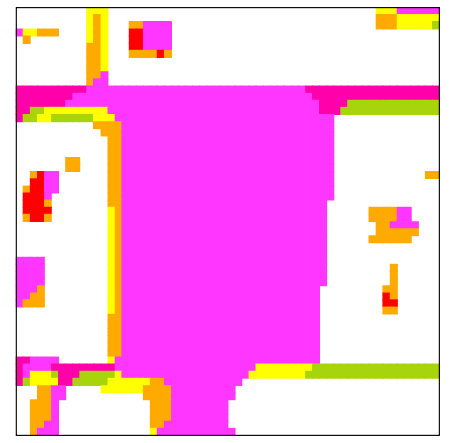

(d)

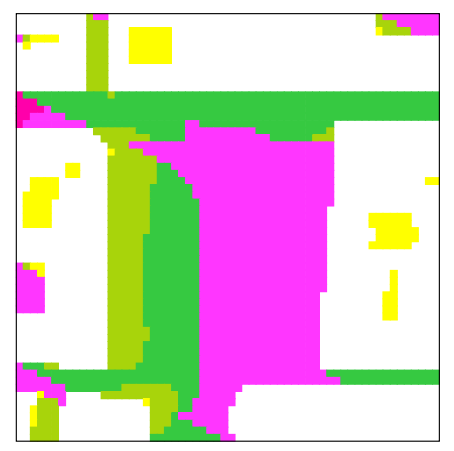

(g)

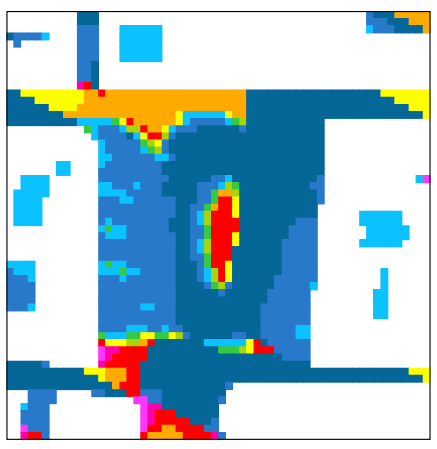

(b)

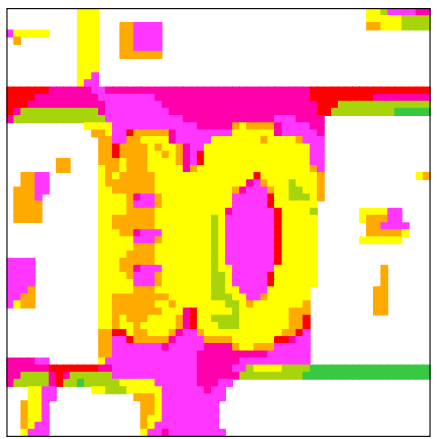

(e)

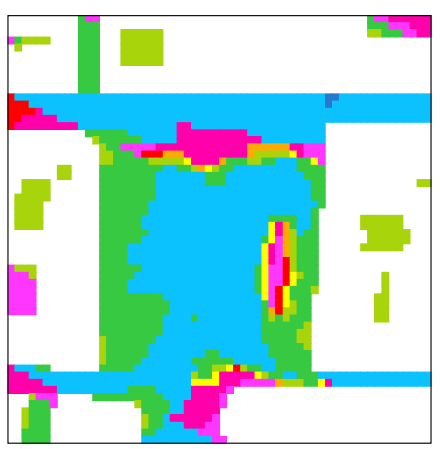

(h)

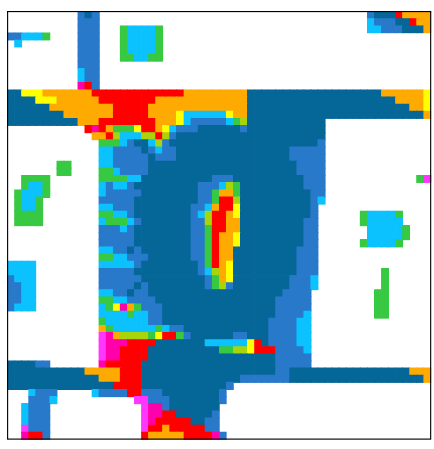

(c)

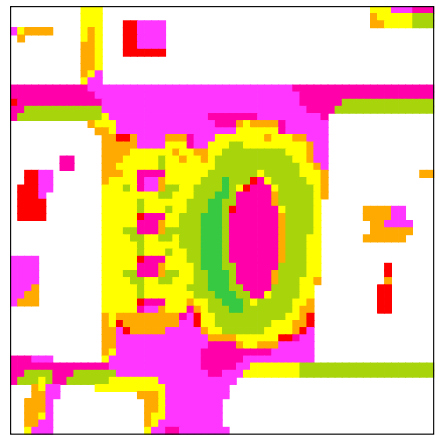

(f)

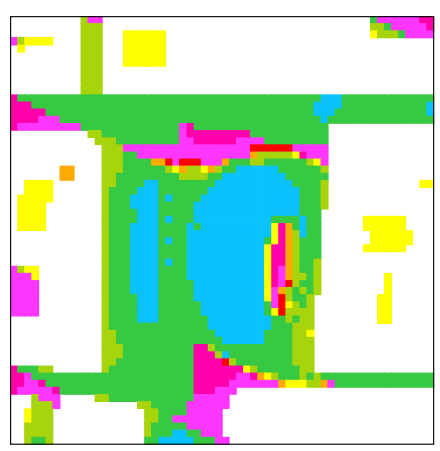

(i)

Figure 5. PET maps at 8:00, 13:00 and 17:00, on the 1 August 2014, of S0 (initial condition), S1 (cool pavements + trees) and S2 (cool roofs + cool walls + trees + grass), in detail: S0 PET at 8:00 (a), S1 PET at 8:00 (b), S2 PET at 8:00 (c), S0 PET at 13:00 (d), S1 PET at 13:00 (e), S2 PET at 13:00 (f), S0 PET at 17:00 (g), S1 PET at 17:00 (h), S2 PET at 17:00 (i).

At 8:00, PET values for scenario S0 (a) range from a minimum value below $22.5^{\circ} \mathrm{C}$ in the SE area of the square, shaded by the surrounding buildings, to a maximum value above $42.5^{\circ} \mathrm{C}$ alongside the western façades of the square, which receives direct solar radiation. Whereas, the central area of the 
square presents a uniform distribution of PET values, between $35^{\circ} \mathrm{C}$ and $37.5^{\circ} \mathrm{C}$. For scenario S1, PET values (b) are consistently lower throughout the square, not only in the shaded areas near the buildings, but also in the areas corresponding to the cool pavements and trees. A limited area on the SW angle of the square and the central area not shaded by trees exhibit PET above $37.5^{\circ} \mathrm{C}$, while the minimum value below $22.5^{\circ} \mathrm{C}$ is located in the same SE area of scenario S0, affected by buildings' shading patterns, and in the central area underneath the Koelreuteria paniculata trees. On NW, under the other trees, Citrus $x$ aurantium and Albizia julibrissin, characterized by with a smaller crown (LAD respectively of $0.55 \mathrm{~m}^{2} / \mathrm{m}^{3}$ and $0.65 \mathrm{~m}^{2} / \mathrm{m}^{3}$ ), PET is comprised between $22.5{ }^{\circ} \mathrm{C}$ and $25.0{ }^{\circ} \mathrm{C}$. Scenario S2 (c) presents a distribution of PET values considerably similar to S1, though with minimum values below $22.5^{\circ} \mathrm{C}$ spreading on a larger area, corresponding to the external portion of the central area shaded by Koelreuteria paniculata trees. Consistently with S0, along the northern façade, the unshaded asphalt area displays PET values between $35.0^{\circ} \mathrm{C}$ and $37.5^{\circ} \mathrm{C}$, while the PET of corresponding area of S1, covered with cool materials, varies between $32.5^{\circ} \mathrm{C}$ and $35.0^{\circ} \mathrm{C}$. At $13: 00, \mathrm{~S} 0$ (d) presents minimum PET values between $32.5^{\circ} \mathrm{C}$ and $35^{\circ} \mathrm{C}$ in the shaded area near the northern façades in the adjacent urban canyons, while maximum PET values above $42.5^{\circ} \mathrm{C}$ comprehend the $90 \%$ of the square exposed to direct solar radiation. The distribution of PET values for S1 (e) mainly coincides with S0 in the periphery of the square, but it is significantly lower in the shaded areas below the trees, where the PET values vary between $32.5^{\circ} \mathrm{C}$ and $35.5^{\circ} \mathrm{C}$, with a reduction of approximately $-8.7^{\circ} \mathrm{C}$ compared to the corresponding unshaded areas in S0. PET values of S2 (f) have a distribution similar to S1, but the absolute values are lower under the Koelreuteria paniculata trees (between $32.5^{\circ} \mathrm{C}$ and $35^{\circ} \mathrm{C}$ for $\mathrm{S} 1$, between $27.5^{\circ} \mathrm{C}$ and $30.0^{\circ} \mathrm{C}$ for S2) and in the unshaded centre of the square (above $42.5^{\circ} \mathrm{C}$ for S1, between $40.0^{\circ} \mathrm{C}$ and $42.5^{\circ} \mathrm{C}$ for S2) and higher in the unshaded asphalt area along the northern façade, which in S1 is covered with cool materials (above $42.5^{\circ} \mathrm{C}$ for S2, between $40.0^{\circ} \mathrm{C}$ and $42.5^{\circ} \mathrm{C}$ for S1). At 17:00, the distribution of PET values for $\mathrm{S} 0(\mathrm{~g})$ is symmetrical to 8:00, following the symmetrical shading patterns, while absolute values are generally higher: the minimum PET values between $27.5^{\circ} \mathrm{C}$ and $32.5^{\circ} \mathrm{C}$ concentrated on the NW areas shaded by buildings, while maximum PET values exceeding $42.5^{\circ} \mathrm{C}$ distributed on the SE areas directly exposed to solar radiation. S1 (h) displays an overall decrease of PET throughout the square, with a minimum of PET between $25.0^{\circ} \mathrm{C}$ and $27.5^{\circ} \mathrm{C}$ in the center of the square, affected by the shade of both groups of trees and the effect of cool materials, and PET between $27.5^{\circ} \mathrm{C}$ and 30.0 along the SE and NW façades. The PET values for S2 (i) mostly correspond to S1, but they are higher along the northern façades, showing the mitigation potential of cool asphalt (S1) in relation to a traditional asphalt (S2), and are lower in the center of the square corresponding to the grass surface and in the inner circle of trees (S2) comparing to a cool pavement (S1).

\subsection{Comparison between Surface Temperature and Thermal Comfort of Different Points of the Square for the Simulation Scenarios}

The percentage and distribution of greenery and cool materials vary for the different areas of the square, whereas the shading patterns, depending on the urban morphology of the area and on the trees arrangement, vary as well. A direct comparison of the surface temperature and PET of 3 points of the square throughout the day for scenario S0, S1 and S2 can stress the coupled effects of these parameters on microclimate and thermal comfort. The selected points depicted in Figure 2, are:

1. point $\mathrm{A}$, corresponding to the measurement point, central and exposed to direct radiation in S0, displays the effect of trees shading and cool and green pavements in S1 and S2;

2. point $\mathrm{B}$, located in the upper NE area of the square, not affected by trees and greenery in any scenario, shows the effect of different artificial pavements on thermal comfort with or without buildings' shade;

3. point $C$, located in the SW area of the square, under two trees and in proximity with the building façade, depicts the interactions between building shading patterns, artificial pavement and greenery (grass and trees). 
Figure 6a shows the daily trend of surface temperature $\left(T_{S}\right)$ among the scenarios at point A. If we consider the general tendency, $T_{s}$ for $\mathrm{S} 0$ starts from a minimum value of $23.4{ }^{\circ} \mathrm{C}$ registered at 8:00, increasing until the peak of $40.5^{\circ} \mathrm{C}$ between $14: 00$ and 15:00, then decreasing till 20:00 with a of $29.0^{\circ} \mathrm{C}$. At 8:00, $T_{S}$ for $\mathrm{S} 1$ presents a value of $23.8^{\circ} \mathrm{C}$, and an increasing trend consistent with $\mathrm{S} 0$ up to $29.5^{\circ} \mathrm{C}$ at 10:00; then the trend changes considerably, with a constant decrease up to $24.0^{\circ} \mathrm{C}$ at $20: 00$. S2, on the other hand, displays a $T_{S}$ at 8:00 of $25.2{ }^{\circ} \mathrm{C}$, slightly higher than scenario $\mathrm{S} 0$ and then follows a trend similar to scenario S1, but lower, with a peak of $29.4{ }^{\circ} \mathrm{C}$ at 10:00 and a minimum of $21.4{ }^{\circ} \mathrm{C}$ at 20:00. Focusing the attention on 8:00,13:00, 17:00, which correspond to the highest momentary attendance (Figure 3), at $8.00 \mathrm{~T}_{\mathrm{S}}$ for $\mathrm{S} 0$ is $23.4^{\circ} \mathrm{C}$, for $\mathrm{S} 1$ is slightly higher, presenting a value of $23.8^{\circ} \mathrm{C}$, whereas it is $25.2^{\circ} \mathrm{C}$ for S2, higher than S0 and S1. At 13:00, $\mathrm{T}_{s}$ for S0 is $39.1^{\circ} \mathrm{C}$, whereas it is $26.5^{\circ} \mathrm{C}$ for $\mathrm{S} 1$ and $24.6{ }^{\circ} \mathrm{C}$ for S2, with a variation from $\mathrm{S} 0$ of $-12.6{ }^{\circ} \mathrm{C}$ and $-14.5^{\circ} \mathrm{C}$ respectively. At 17:00 $T_{S}$ for S0 is $37.3^{\circ} \mathrm{C}$, for S1 $26.1^{\circ} \mathrm{C}, 24.2^{\circ} \mathrm{C}$ for S2, with a significant decrease of $-11.2^{\circ} \mathrm{C}$ and $-13.1{ }^{\circ} \mathrm{C}$ comparing to scenario S0.

Figure $6 \mathrm{~b}$ shows the daily trend of $T_{S}$ among the scenarios for point $\mathrm{B} . T_{S}$ for $\mathrm{S} 0$ slightly increases from the initial value of $22.1{ }^{\circ} \mathrm{C}$ at $8: 00$ up to $27.4{ }^{\circ} \mathrm{C}$ at $11: 00$, then it abruptly increases to $39.6{ }^{\circ} \mathrm{C}$ at 12:00, when the shade of the surrounding buildings recedes, with a peak of $44.6^{\circ} \mathrm{C}$ at $14: 00$ and a decrease up to $29^{\circ} \mathrm{C}$ at 20.00. S2 shows a considerably similar trend, overlapping and, in some hours, also exceeding the value of $\mathrm{S} 0$, whereas $T_{S}$ for $\mathrm{S} 1$ is drastically lower, with a minimum of $22.5^{\circ} \mathrm{C}$ at 8:00 and a maximum of $27.6{ }^{\circ} \mathrm{C}$ at 16:00. Comparing $T_{S}$ at 8:00, 13:00, 17:00 for the three scenarios, at 8:00, S0 presents a $T_{S}$ for $22.1^{\circ} \mathrm{C}$, while S1 of $20.7^{\circ} \mathrm{C}$ and S2 of $22.5^{\circ} \mathrm{C}$, with a difference with S0 of $-1.4{ }^{\circ} \mathrm{C}$ and $+0.4{ }^{\circ} \mathrm{C}$. At 13:00, S0 displays a $T_{S}$ of $43.1{ }^{\circ} \mathrm{C}$, for $\mathrm{S} 1$ the corresponding value of $26.5^{\circ} \mathrm{C}$ is significantly lower, whereas S2 appears to have a similar $T_{S}$ as $\mathrm{S} 0$, with a value of $43.6^{\circ} \mathrm{C}$. The differences between S1 and S2 with S0 are, respectively, $-16.6^{\circ} \mathrm{C}$ and $+0.5^{\circ} \mathrm{C}$. At $17: 00, T_{s}$ for S0 is $40.5^{\circ} \mathrm{C}$, whereas for S1 it is $27.3^{\circ} \mathrm{C}$, with a notable decrease of $26.8^{\circ} \mathrm{C}$, and $40.4^{\circ} \mathrm{C}$ for S2, only $0.1^{\circ} \mathrm{C}$ lower.

Figure $6 \mathrm{c}$ shows the daily trend of $T_{S}$ among the scenarios for point $\mathrm{C}$. $T_{S}$ for $\mathrm{S} 0$ rises from $24.9{ }^{\circ} \mathrm{C}$ at 8.00 to $41.4{ }^{\circ} \mathrm{C}$ at $14: 00$, then it significantly decreases to $35.4{ }^{\circ} \mathrm{C}$ at $15: 00$, when the point starts being shaded, until 20:00 when $T_{S}$ is around $25.0^{\circ} \mathrm{C}$. S1 and S2 present a daily trend lower than S0: S1 has a slight rise from $22{ }^{\circ} \mathrm{C}$ at 8:00 to $27.0^{\circ} \mathrm{C}$ at 14:00, then it decreases till 24.5 at 20:00. On the other hand, S2 displays values lower than S0 but slightly higher than $\mathrm{S} 1$ from $22.2^{\circ} \mathrm{C}$ at $8: 00$ to $26.8^{\circ} \mathrm{C}$ at $14: 00$, then it constantly decreases until $22.3^{\circ} \mathrm{C}$ at 20:00. Taking into account the three selected hours, $T_{S}$ at 8:00 for S0 is $24.9{ }^{\circ} \mathrm{C}$, whereas $\mathrm{S} 1$ has a $T_{S}$ of $22{ }^{\circ} \mathrm{C}$ and S2 a similar value of $22.2^{\circ} \mathrm{C}$, both with a difference towards $\mathrm{S} 0$ of $-3.0^{\circ} \mathrm{C}$ approximately. At $13: 00$, the $T_{s}$ for $\mathrm{S} 0$ is $40.5^{\circ} \mathrm{C}$, whereas $\mathrm{S} 1$ presents a value of $26.4^{\circ} \mathrm{C}$ and scenario S2 a value of $28^{\circ} \mathrm{C}$. The relative difference between $\mathrm{S} 0$ and the other two scenarios is $-14{ }^{\circ} \mathrm{C}$ for $\mathrm{S} 1$ and $-12.5^{\circ} \mathrm{C}$ for S2. At $17.00, T_{s}$ for $\mathrm{S} 0$ is $32.1{ }^{\circ} \mathrm{C}$, whereas for $\mathrm{S} 1$ is $26.4{ }^{\circ} \mathrm{C}$ and for $\mathrm{S} 2$ is $25.4{ }^{\circ} \mathrm{C}$. In this case, the difference between $\mathrm{S} 0$ and $\mathrm{S} 1$ is around $-6^{\circ} \mathrm{C}$, between $\mathrm{S} 0$ and $\mathrm{S} 2$ is around $-7.0^{\circ} \mathrm{C}$.

As shown in Figure 7a, which represents the daily trends of PET values for point A, S0 displays a PET value of $36.8^{\circ} \mathrm{C}$ at $8: 00$, it increases until a peak of $47.8^{\circ} \mathrm{C}$ at $15: 00$ and then shows an abrupt decrease between $16: 00$ and 17:00, with a value of $25.1^{\circ} \mathrm{C}$, until the evening at 20:00, when it reaches $20.1^{\circ} \mathrm{C}$. PET trends for S1 and S2 are similar and appear to have lower values corresponding to S0 throughout the day, except in the morning at 8:00 and 9:00, when both scenarios have slightly higher values than S0. In general, PET for S1 is higher than for S2: in fact, S0 has a mean PET difference with $\mathrm{S} 1$ and $\mathrm{S} 2$ of $-7.2{ }^{\circ} \mathrm{C}$ and $-8.4{ }^{\circ} \mathrm{C}$ respectively, while the difference of mean PET between S1 and S2 corresponds to $+1.2^{\circ} \mathrm{C}$. 


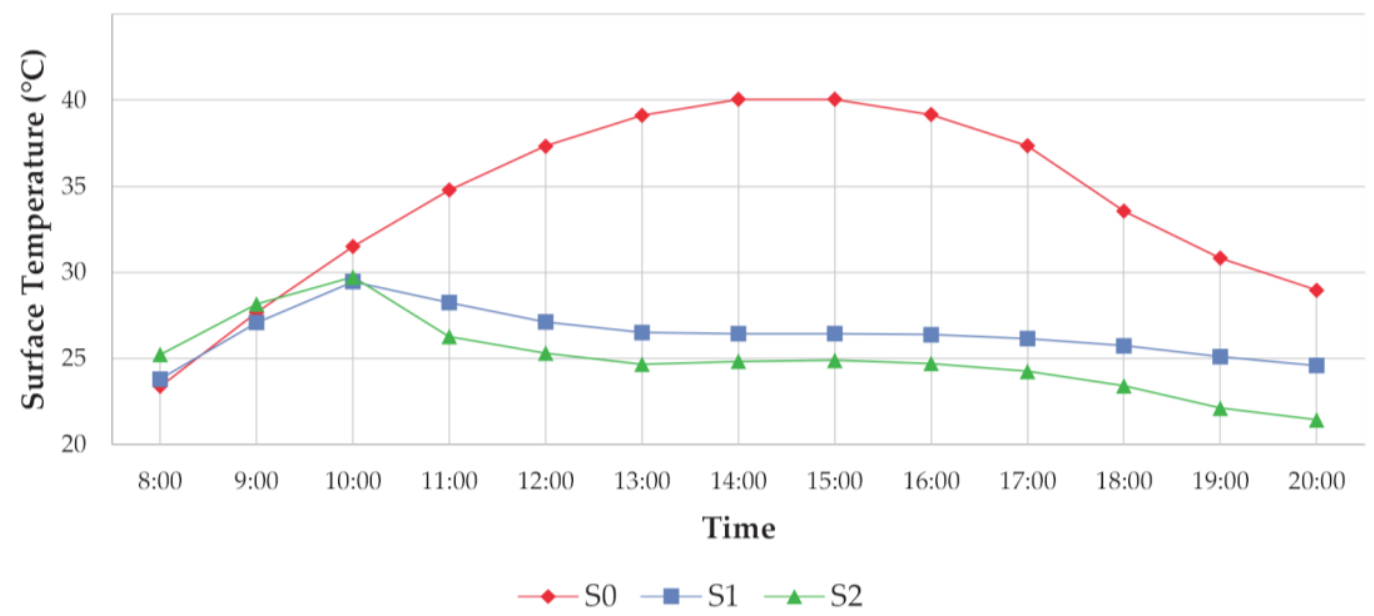

(a)

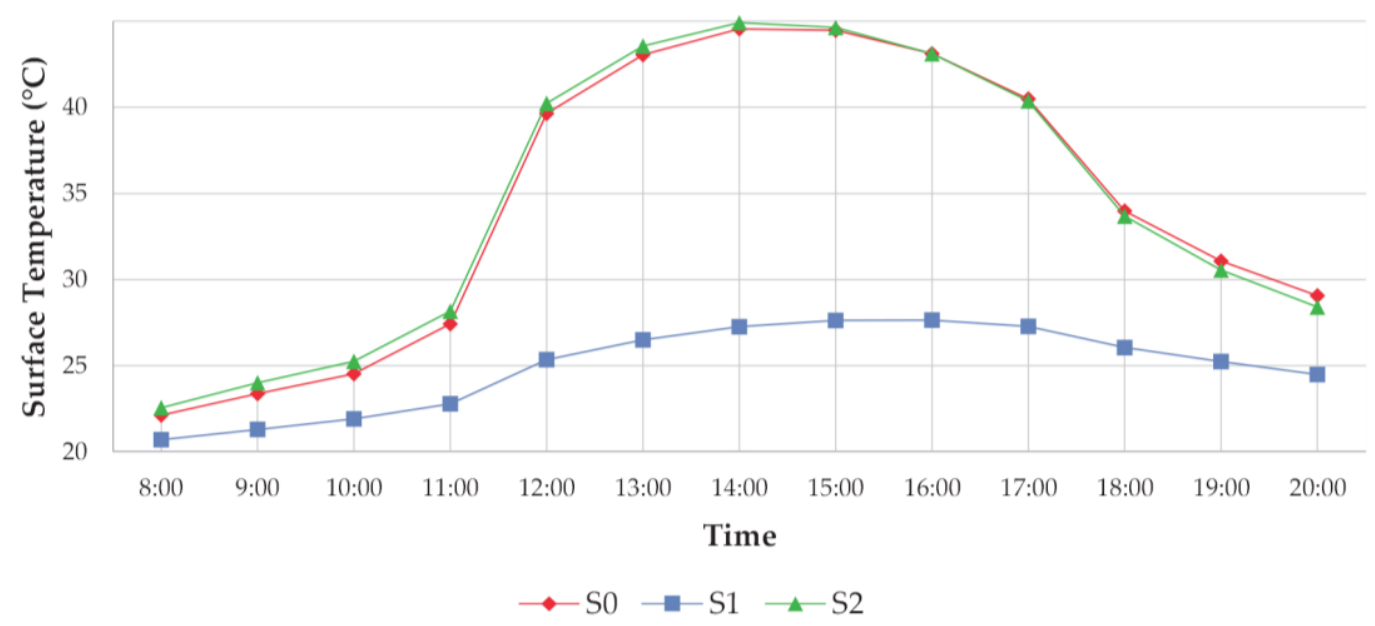

(b)

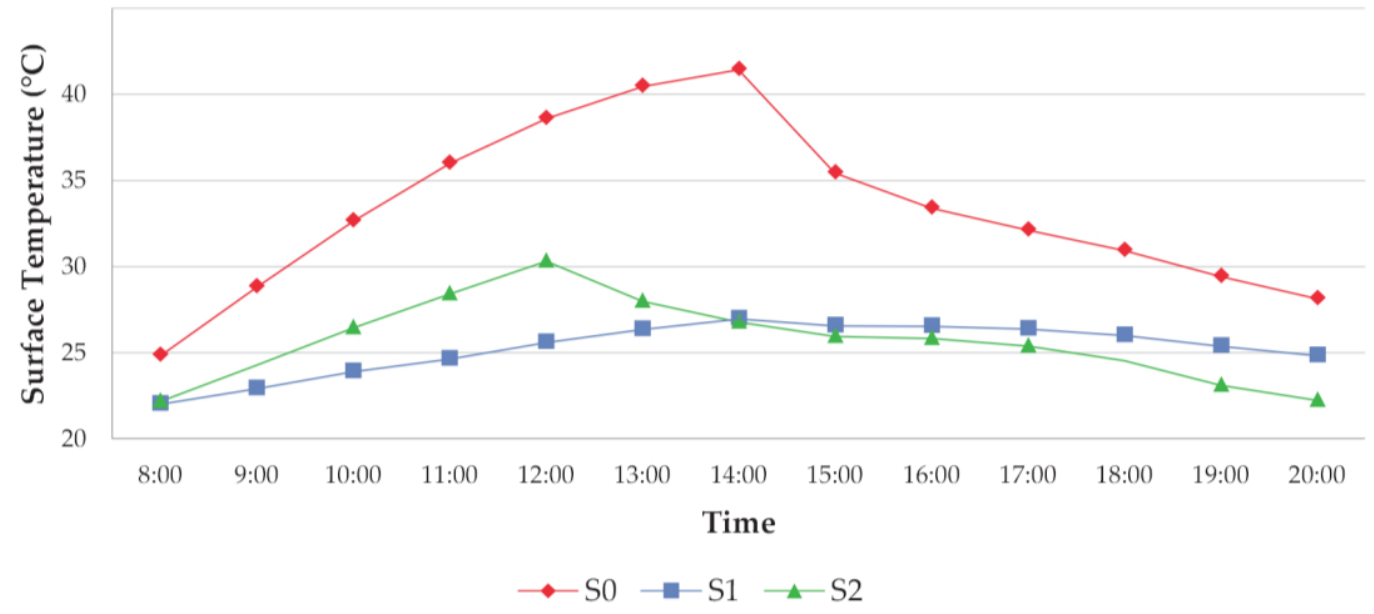

(c)

Figure 6. (a) Daily trend, on the 1st August 2014, of surface temperature $\left(T_{S}\right)$ in point A among the three scenarios: S0 (initial condition), S1 (cool pavements + trees) and S2 (cool roofs + cool walls + trees + grass); (b) daily trend of surface temperature $\left(T_{S}\right)$ in point B among the three scenarios: S0, S1, S2; (c) daily trend of surface temperature $\left(T_{S}\right)$ in point $C$ among the three scenarios: $S 0, S 1, S 2$. 

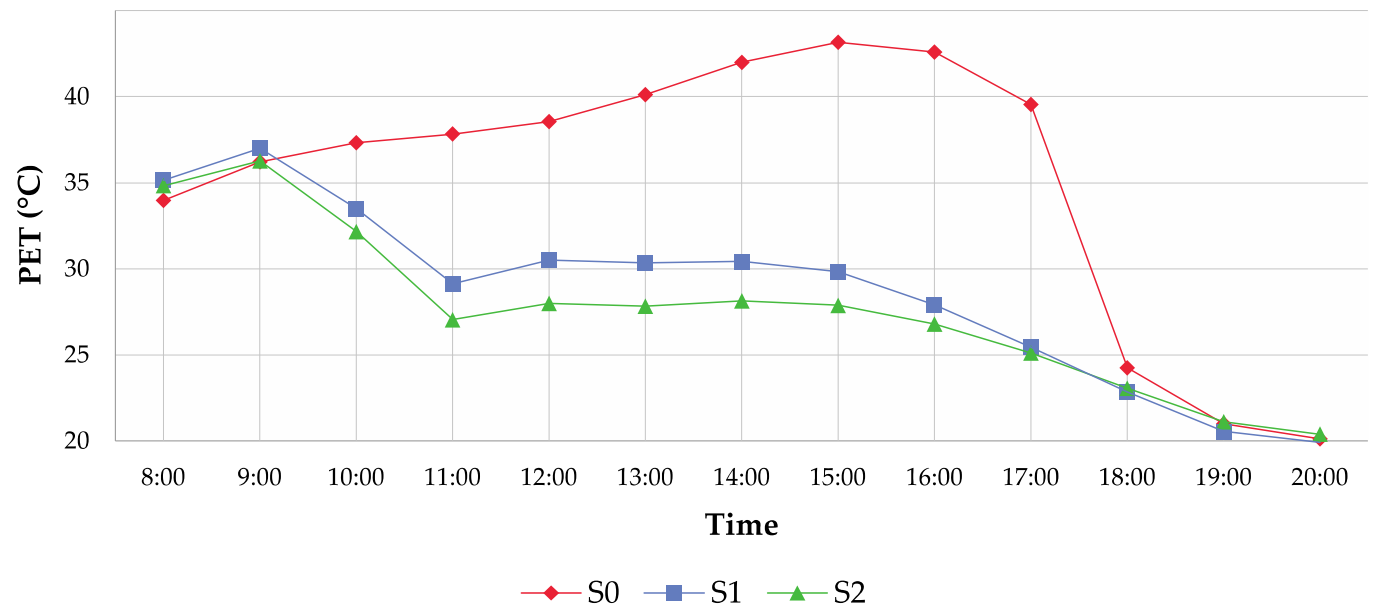

(a)
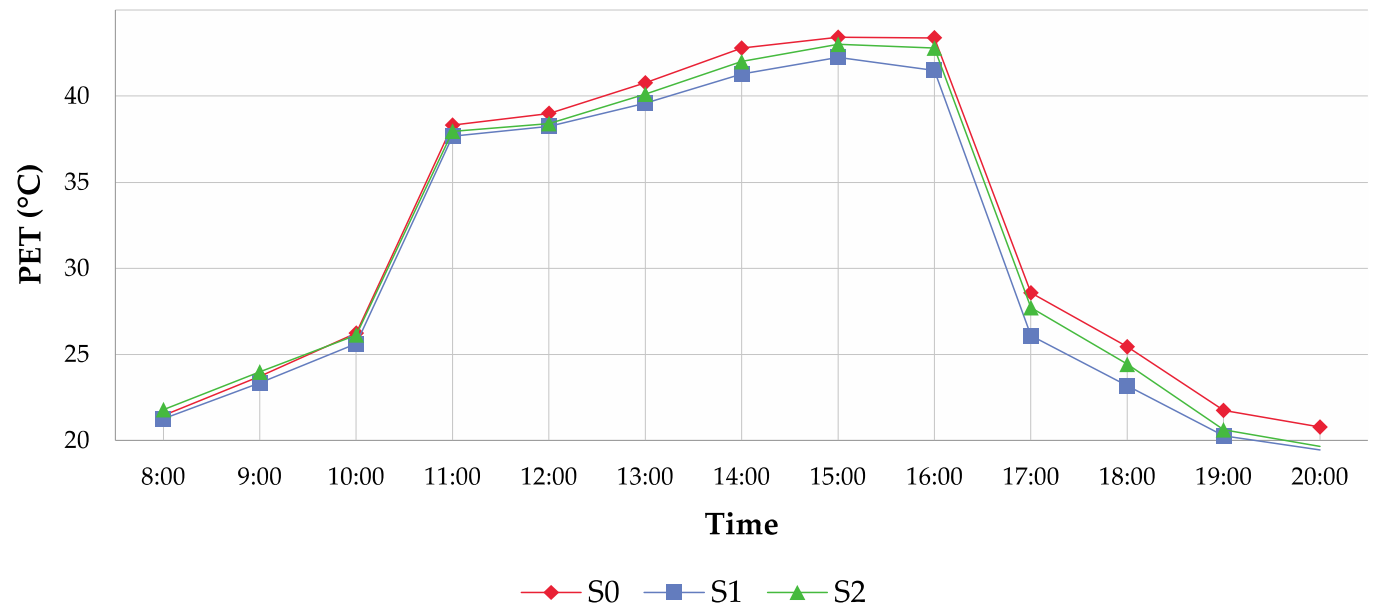

(b)

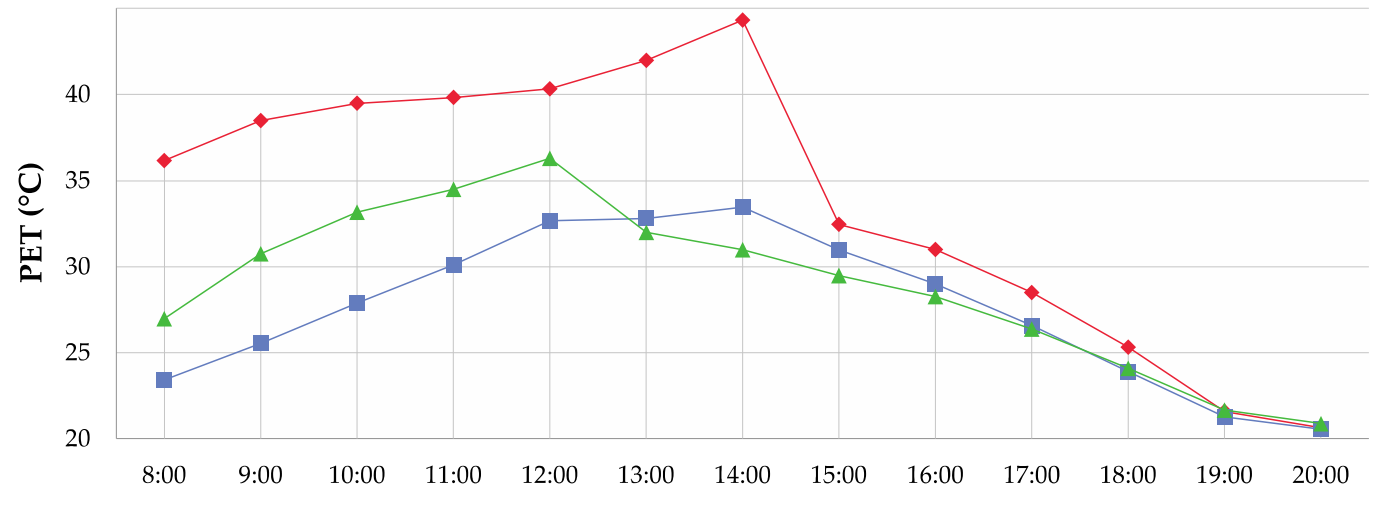

Time

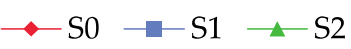

(c)

Figure 7. (a) Daily trend, on 1st August 2014, of PET values in point A among the three scenarios: S0 (initial condition), S1 (cool pavements + trees) and S2 (cool roofs + cool walls + trees + grass); (b) daily trend of PET values in point B among the three scenarios: S0, S1, S2; (c) daily trend of PET values in point $C$ among the three scenarios: S0, S1, S2. 
If we consider PET values for the scenario at 8:00, 13:00 and 17:00, at 8:00 S0 presents a PET value of $36.8^{\circ} \mathrm{C}$, whereas S1 a PET of $38.2^{\circ} \mathrm{C}$ and S2 a PET of $37.8^{\circ} \mathrm{C}$. The difference between S0 with S1 and $\mathrm{S} 2$ are of $+1.4{ }^{\circ} \mathrm{C}$ for S1 and of $-1{ }^{\circ} \mathrm{C}$ for S2. At 13:00, the PET value for S0 is $44.1^{\circ} \mathrm{C}$, S1 presents a PET of $32.4{ }^{\circ} \mathrm{C}$ and for S2 the PET value is $29.4{ }^{\circ} \mathrm{C}$, with a variation of $-12{ }^{\circ} \mathrm{C}$ for S1 and $-15{ }^{\circ} \mathrm{C}$ for S2 against S0. At 17:00, S0 presents a PET value of $43.5^{\circ} \mathrm{C}$, whereas $\mathrm{S} 1$ depicts a value of $26.5^{\circ} \mathrm{C}$ and similarly S2 a value of $26.1^{\circ} \mathrm{C}$.

Figure $7 \mathrm{~b}$ shows the daily trends of PET for point B. In this case, all the three scenarios display a very similar tendency in terms of intensity and daily distribution of PET, since point $B$ is far from the direct effects of trees and vegetation and, compared to S0, the most relevant changed urban design parameter for S1 is the cool pavement, whereas for S2 it is the cool material of the near building façades. The scenarios present an PET value at 8:00 between $21.0^{\circ} \mathrm{C}$ and $22.0^{\circ} \mathrm{C}$, then they all increase consistently after 10:00, when shade from the buildings moves, until they reach the peak at 15:00 with PET values between $47.0^{\circ} \mathrm{C}$ and $48.0^{\circ} \mathrm{C}$, and then they decrease suddenly 15:00 and 16:00, when the point is shaded again, with PET values around $29.0^{\circ} \mathrm{C}$, continuing to decrease until 20:00 with PET values of about $20.0^{\circ} \mathrm{C}$. The mean PET difference for S1 and S2 in relation to scenario S0 is, respectively, $-1.3^{\circ} \mathrm{C}$ and $-0.6^{\circ} \mathrm{C}$. At 8:00, S0 presents a PET value of $21.7^{\circ} \mathrm{C}$, whereas S1 registers a PET of $21.5^{\circ} \mathrm{C}$ and S2 a PET of $22.1^{\circ} \mathrm{C}$. The difference between S1 and S2 to S0 are of $-0.2{ }^{\circ} \mathrm{C}$ for S1 and of $+0.4^{\circ} \mathrm{C}$ for S2. At 13:00, the PET value of $\mathrm{S} 0$ is $44.1^{\circ} \mathrm{C}, \mathrm{S} 1$ presents a PET of $43.5^{\circ} \mathrm{C}$ and S2 a PET value of $44.1^{\circ} \mathrm{C}$, registering a variation of $-0.6{ }^{\circ} \mathrm{C}$ for $\mathrm{S} 1$ in relation to $\mathrm{S} 1$, and no variation for S2. At 17:00, S0 presents a PET value of $30.3^{\circ} \mathrm{C}$, whereas $\mathrm{S} 1$ of $27.3^{\circ} \mathrm{C}$ and $\mathrm{S} 2$ of $29.2^{\circ} \mathrm{C}$, decreasing of $-3^{\circ} \mathrm{C}$ and $-1.1^{\circ} \mathrm{C}$ from S0, respectively.

Figure 7c shows the daily trend of PET values among the three scenarios for point $\mathrm{C}$. In this case, the PET of S0 presents generally a higher tendency in relation to S1 and S2. It is rather high at 8:00, with a value of $39.4{ }^{\circ} \mathrm{C}$, then it increases until it reaches the peak at $14: 00$, when it measures $49.2^{\circ} \mathrm{C}$ and then it decreases suddenly at 15:00, with a value of $34.5^{\circ} \mathrm{C}$, until it reaches the minimum at 20:00, with a value of $20.8^{\circ} \mathrm{C}$. Regarding S1, PET presents a steady rise from $24.1^{\circ} \mathrm{C}$ at $8: 00$ to $33.2^{\circ} \mathrm{C}$ at 14:00 and then a decrease until 20:00, when the PET value is $20.5^{\circ} \mathrm{C}$. S2 presents higher PET values than $\mathrm{S} 1$ from 8:00 to the maximum of $34.4^{\circ} \mathrm{C}$ at 12:00, then it decreases, with values lower than the corresponding of $\mathrm{S} 2$, until 19:00 and 20:00 when it measures $22.0^{\circ} \mathrm{C}$ and $21.6^{\circ} \mathrm{C}$, again slightly higher than S1. The mean PET differences of S1 and S2 in relation to S0 is, respectively, around $-7.0^{\circ} \mathrm{C}$ and $-5.5^{\circ} \mathrm{C}$, whereas the difference in terms of mean PET value for $\mathrm{S} 1$ in relation to $\mathrm{S} 2$ is around $-1.5^{\circ} \mathrm{C}$. Considering the three selected hours, at 8:00 the PET value for $\mathrm{S} 0$ is $39.4^{\circ} \mathrm{C}$, for $\mathrm{S} 1$ is $24.1^{\circ} \mathrm{C}$ and for S2 is $28.4{ }^{\circ} \mathrm{C}$. At 13:00, the PET for S0 reaches $46.4{ }^{\circ} \mathrm{C}$, whereas for S1 the PET is equal to $35.4{ }^{\circ} \mathrm{C}$ and for $\mathrm{S} 2$ to $34.4{ }^{\circ} \mathrm{C}$, displaying a difference in relation to $\mathrm{S} 0$ of $-11^{\circ} \mathrm{C}$ and of $-12{ }^{\circ} \mathrm{C}$, respectively. At 17:00, S0 displays a PET value of $30.2^{\circ} \mathrm{C}$, S1 shows a PET value of $27.9^{\circ} \mathrm{C}$ and S2 a PET value of $27.6^{\circ} \mathrm{C}$, with a difference in relation to $\mathrm{S} 0$ of about $-2.3{ }^{\circ} \mathrm{C}$ for $\mathrm{S} 1$ and $-2.6{ }^{\circ} \mathrm{C}$ for $\mathrm{S} 2$.

The following tables, Tables 4 and 5, offer a systematic overview of the surface temperature and PET values' trends throughout the day in the investigated scenarios, in order to underline the minimum and maximum values as well as the general trends of each scenarios.

Table 4. Principal surface temperature values in point A, B and C for scenarios S0 (initial condition), S1 (cool pavements + trees) and S2 (cool roofs + cool walls + tress + grass) at 8:00, 14:00 and 17:00, on 1 August 2014.

\begin{tabular}{cccccccccc}
\hline \multirow{2}{*}{ Time } & \multicolumn{3}{c}{$\boldsymbol{T}_{\boldsymbol{S}}(\mathbf{A})$} & \multicolumn{3}{c}{$\boldsymbol{T}_{\boldsymbol{S}} \mathbf{( B )}$} & \multicolumn{3}{c}{$\boldsymbol{T}_{\boldsymbol{S}}(\mathrm{C})$} \\
\cline { 2 - 10 } & S0 & S1 & S2 & S0 & S1 & S2 & S0 & S1 & S2 \\
\hline $8: 00$ & 23.4 & 23.8 & 25.2 & 22.1 & 20.7 & 22.6 & 24.9 & 22.1 & 22.2 \\
$14: 00$ & 40.0 & 26.4 & 24.8 & 44.6 & 27.3 & 44.9 & 41.4 & 27.0 & 26.8 \\
$17: 00$ & 37.4 & 26.1 & 24.2 & 40.5 & 27.3 & 40.4 & 32.1 & 26.4 & 25.4 \\
\hline
\end{tabular}


Table 5. Principal PET values in point A, B and C for scenarios S0 (initial condition), S1 (cool pavements + trees) and S2 (cool roofs + cool walls + tress + grass) at 8:00, 14:00 and 17:00, on 1 August 2014.

\begin{tabular}{cccccccccc}
\hline \multirow{2}{*}{ Time } & \multicolumn{3}{c}{ PET (A) } & \multicolumn{3}{c}{ PET (B) } & \multicolumn{3}{c}{ PET (C) } \\
\cline { 2 - 10 } & S0 & S1 & S2 & S0 & S1 & S2 & S0 & S1 & S2 \\
\hline $8: 00$ & 36.8 & 38.2 & 37.8 & 21.7 & 21.5 & 22.1 & 39.4 & 24.1 & 28.4 \\
$14: 00$ & 46.4 & 32.5 & 29.8 & 47.3 & 45.5 & 46.4 & 49.2 & 36.2 & 33.2 \\
$17: 00$ & 43.5 & 26.5 & 26.1 & 30.3 & 27.3 & 29.2 & 30.2 & 27.9 & 27.7 \\
$19: 00$ & 21.2 & 20.7 & 21.3 & 22.1 & 20.3 & 20.7 & 21.9 & 21.5 & 22.0 \\
\hline
\end{tabular}

\section{Discussion}

The field analysis of the microclimatic conditions and attendance on 1st August 2014 in San Silvestro Square has highlighted the close connection between the usage of square and outdoor thermal comfort, which is influenced by the morphological features of the urban open space, especially by the shading patterns: in fact, the significantly lower PET values of shaded locations consistently correspond to higher attendance rates.

These results are visible in Figure 3 that compares shading patterns and attendance rate and in Figure 4 that illustrates the PET values in the shaded and unshaded areas of the square, the $T_{m r t}$ in this case has been calculated as shown in Table 3 but not illustrated in a graph since it represents only a part of the more complex thermal comfort sensation; thus, it is more accurate and easy to understand to compare the PET index with shading patterns and attendance rate. In fact, if we take a closer look at the data exposed in the graph (Figure 3 ) and consider as reference hours the early morning and evening: 8:00 and 18:00, excluding the interval between 12:00 and 13:00 because of the extended solar radiation in the square, it appears clearly that at 8:00 when the shaded areas comprises all of the square surfaces (100\% of shaded area), the registered average momentary attendance is 18 people, corresponding to a PET value of $26{ }^{\circ} \mathrm{C}$ (Figure 4); the correlation between shaded areas, attendance rate and thermal comfort is confirmed at 18:00 when the shaded area percentage is about $60 \%$ of total area of the square and the registered average momentary attendance in shaded locations is 80 people corresponding to a PET value of $30{ }^{\circ} \mathrm{C}$ (Figure 4), whereas at the same hour in the evening (18:00) in unshaded locations (about $40 \%$ of the square) the average momentary attendance is 5 people corresponding to a PET value of $32{ }^{\circ} \mathrm{C}$ (Figure 4 ).

Based on this finding, the second stage of the study proposes a simulation analysis of two renovation scenarios, S1 and S2, against the existing conditions scenario S0, taking into account the behavior of cool materials and vegetation, in terms of trees and grass, on outdoor thermal comfort focusing the attention on the pedestrian level.

If we consider the PET variations displayed by the two renovation scenarios, both S1 and S2 show a larger distribution of lower PET values during the day comparing to S0. Especially at 13:00, S1 (Figure 5e) depicts a larger distribution of PET values between $32.5^{\circ} \mathrm{C}$ and $35^{\circ} \mathrm{C}$ while S2, (Figure $5 \mathrm{f}$ ) displays a larger distribution of PET values between $27.5^{\circ} \mathrm{C}$ and $30^{\circ} \mathrm{C}$, demonstrating their mitigation potential of the outdoor thermal comfort during extreme microclimatic conditions.

Regarding the effect of vegetation, the study highlights the significant mitigation potential of trees, which is in line with Ketterer [37] findings. This potential mainly depends on the obstruction of direct solar radiation, which is determined by the trees' geometry, characteristics of the crown and LAD (leaf area density, $\mathrm{m}^{2} / \mathrm{m}^{3}$ ). In fact, in S1, Figure $5 \mathrm{e}$, as well as in S2, Figure $5 \mathrm{f}$, the minimum PET values between $27.5^{\circ} \mathrm{C}$ and $30^{\circ} \mathrm{C}$, are concentrated underneath the Koelreuteria paniculata tree crowns, that presents the highest value of LAD in the square $\left(0.75 \mathrm{~m}^{2} / \mathrm{m}^{3}\right)$, whereas underneath the Citrus $x$ aurantium and the Albizia julibbrissin, that present lower LAD values (respectively of $0.55 \mathrm{~m}^{2} / \mathrm{m}^{3}$ and $0.65 \mathrm{~m}^{2} / \mathrm{m}^{3}$ ), the PET values vary between $32.5{ }^{\circ} \mathrm{C}$ and $35^{\circ} \mathrm{C}$. This impact appears to be more relevant than the "artificial shade" casted by buildings, probably on the account of their evapotranspiration processes. An example of higher PET values under building shade is visible in 
Figure 5e where, in those area underneath the shade of surrounding buildings, for example between point $C$ and the near building's façade or in the courtyard located at the western side of the square, the PET values are slightly higher ranging between $35^{\circ} \mathrm{C}$ and $37.5^{\circ} \mathrm{C}$.

Concerning the cool materials, it is important to underline how the present study does not attempt to model all aspects of the complex human response to high-albedo environments which, as stated by Erell et al. [57], is likely to be affected by other considerations in addition to thermal comfort, such as visual comfort; this concerns especially S1 that models and analyzes a cool material characterized by a white appearance and thus a high albedo, whereas S2 models and analyzes a cool colored materials, that presents a light orange colored appearance.

Whether cool materials are applied on pavements (cool pavements) or on façades (cool walls), they exhibit, as expected, a significant cooling effect on surface temperature, which correspond to a variable mitigation effect on thermal comfort, especially when they are directly exposed to solar radiation, without the contribution of natural or artificial shadings. Their performance in lowering the surface temperature can be observed in Figure 6. If we consider a point near a building façade and directly exposed to the solar radiation, as in Figure $6 \mathrm{~b}$ (point $\mathrm{B}$ ), the difference between the Ts of $\mathrm{S} 1$ in relation to S0 and S2 is significant: the cool pavement modelled in S1 $(\alpha=0.89)$, when exposed directly to solar radiation, registers lower Ts values both compared to S0 and to S2 throughout the day and especially at the peak hour at 14:00 $\left(T_{S}(\mathrm{~S} 1)=27.3^{\circ} \mathrm{C}\right)$, when the difference between $T s$ of $\mathrm{S} 1$ in relation to Ts of S0 and S2 is around $-17{ }^{\circ} \mathrm{C}\left(T_{S}(\mathrm{~S} 0)=44.6{ }^{\circ} \mathrm{C}\right.$; $\left.T_{s}(\mathrm{~S} 2)=45^{\circ} \mathrm{C}\right)$. Regarding the difference between Ts of $\mathrm{S} 1$ and Ts of $\mathrm{S} 2$ in point $\mathrm{B}$, it is related most likely to the nearby cool wall effect, thus leading to a possible contribution of the cool wall in slightly increasing the $T s$ of the pavement nearby, around $+2{ }^{\circ} \mathrm{C}$ at 14:00. On the other hand, if the cool pavement is shaded by a tree, as shown in Figure $6 \mathrm{a}$ at point $\mathrm{A}$, its $T_{s}$ values are lower than the $T_{s}$ values of $\mathrm{S} 0\left(\mathrm{~T}_{S}(\mathrm{~S} 1)=26.4^{\circ} \mathrm{C}\right.$; $\left.\mathrm{Ts}(\mathrm{S} 0)=40^{\circ} \mathrm{C}\right)$, around $-13^{\circ} \mathrm{C}$ at $14: 00$, but they are slightly higher than those registered by the combined effect of grass and tree in $\mathrm{S} 2\left(24.8^{\circ} \mathrm{C}\right)$, with a difference at $14: 00$ of $+1.6^{\circ} \mathrm{C}$. This is most likely due to the coupled effect of the tree' shading and the evapotranspiration process between tree and grass, contributing to the lowering the $T_{s}$. However, cool pavements display a better performance in lowering $T s$ than grass during the early hours of the morning as visible in Figure 6a, from 8:00 to 13:00. Cool materials generally have a mitigating effect on thermal comfort, but their performance is variable, due to their complex effect on the radiative environment: in fact, Figure 7a shows higher PET values at 8:00 and 9:00 for $\mathrm{S} 1\left(38.2{ }^{\circ} \mathrm{C}\right.$ and $40.4{ }^{\circ} \mathrm{C}$, respectively) in comparison to $\mathrm{S} 0\left(36.7^{\circ} \mathrm{C}\right.$ and $\left.39.4{ }^{\circ} \mathrm{C}\right)$. Moreover, Figure $7 \mathrm{~b}$, shows that cool pavements of $\mathrm{S} 1$ presents lower PET values than $\mathrm{S} 0$ at $14: 00$, around $-2{ }^{\circ} \mathrm{C}$, but slightly higher than $\mathrm{S} 2$, around $+1{ }^{\circ} \mathrm{C}$, due most likely to the contribution of the cool wall on a cobblestone pavement. This finding is in line with Erell et al. [57], and it presumably depends on the reflected solar radiation, which can either be absorbed by the surrounding surfaces increasing their surface temperature [21] or directly by the human body, increasing its energy balance.

Considering shaded cool materials, the coupled effect of tree and an impervious high reflective cool colored pavement of S1 results in lower PET values than the existing impervious low albedo pavement of S0 (Figure 5e), but conversely in higher PET values than the combination of tree and grass of S2 depicted in Figure 5f. This is most likely due to the evapotranspiration and metabolic processes of both tree and grass.

\section{Conclusions}

The current study presents a two-step analysis, centered first on the evaluation of the connection between shade and thermal comfort, through a field analysis of the thermal and radiative environment on the 1st and 2nd August 2014, highlighting the effect of daily shading patterns on thermal comfort in urban open spaces under extreme microclimate conditions, by means of attendance studies in San Silvestro square, in Rome. In the second stage, the study, by means of a single day microclimate simulation on 1st August 2014, focuses the attention on the evaluation of the mitigation effect that two selected renovation scenarios based on urban greenery and advanced materials, such as cool 
colored materials, have on outdoor thermal comfort conditions in existing open spaces, in the light of increasing urban overheating.

Thus, it must be underlined that the study represents a very specific analysis on outdoor thermal comfort in a square of the historical Mediterranean tissue. Firstly, because the results analyzed applied under a limited set of meteorological conditions, collected at one site and over two days during the summer period. Second, because of the typology of the space investigated: in fact, all the renovation scenarios have been modelled and studied for a type of square considered typical of the historical tissue of the city of Rome, in terms of size, height of surrounding buildings, H/W ratio and SVF. Consequently, this also implies that the technologies and scenarios analyzed can be replicated in other urban historical squares characterized by a similar $\mathrm{H} / \mathrm{W}$ ratio and SVF, in which there is a direct effect on the outdoor microclimate from the surrounding built environment, particularly from the urban façades and pavements. Third, because the type of materials used and inquired, in fact even though characterized by high albedo coefficients, on the other hand they constitute a small percentage of the expanding high reflective materials class, thus more investigations are required for other combinations and solutions in this regard.

From the point of view of urban design and urban planning, the research emphasizes the importance of outdoor thermal comfort concerns within the renovation of open spaces and demonstrates the potential of well-chosen "minimum intervention" solutions, respectful of the traditional image of the city, as a driving principle for the sustainable renovation and adaptation of the historic tissues to urban overheating.

The results of this study suggest two main microclimatic aspects relevant for informing urban designers in the renovation processes of the historical tissues. Firstly, the correlation between shading patterns and thermal comfort highlighted by the attendance rate in the square conducted in the first stage of the study; promotes the widespread use of shading devices, integrated with local urban morphology and usage patterns. Second, the different upgrade in terms of pedestrian thermal comfort offered by trees and advanced materials technologies, such as cool pavements, in urban open spaces. In fact, the second stage of analysis highlights the effective result that innovative surface materials can have on urban overheating, especially when coupled with natural shading devices, such as trees.

In general, the findings from this study show how greenery appears to have a better effect on outdoor thermal comfort than traditional artificial materials, because of the influence of evapotranspiration on the cooling loads [37]: in fact, the second renovation scenario (S2) with an extensive use of trees and grass pavements, shows the largest distribution of lower PET values in hours of the day with the highest attendance (Figure 5).

Nevertheless, cool pavements can also bring a tangible improvement on urban environment, as they generally have a positive mitigating effect on outdoor thermal comfort and are less expensive and with low maintenance rate than vegetated surfaces [49]. However, their interaction with the radiative environment and the higher reflection of solar radiation could have a counteracting effect [21], especially when coupled with high reflective walls, thus their use requires an attentive evaluation going beyond surface temperature and air temperature analysis, but focused on overall comfort parameters such as PET index. In addition, it could be relevant to investigate the effects that high reflective materials have, not only on the microscale but on the large scale as well, if applied on pavements and façades as well.

Particularly, if we consider the different results among the three case studies scenarios at 13:00, selected because of the high solar irradiance, the performance of the cooling technologies and strategies investigated is evident. Both the renovation scenarios, the first scenario (cool pavements + trees) and the second scenario (cool roofs + cool walls + trees + grass), show, as aforementioned, a general upgrade of the thermal conditions regarding the Ts values and specifically the PET values.

$T_{S}$ was found to be $16.6{ }^{\circ} \mathrm{C}$ lower in correspondence of a cool pavement characterized by a high albedo $(\mathrm{a}=0.89)$ and exposed to direct solar radiation (point $\mathrm{B}$, first scenario) as visible in Figure $6 \mathrm{~b}$, whereas it was found to be $0.5^{\circ} \mathrm{C}$ higher, in the same location, for the second scenario 
in correspondence of grass $(\mathrm{a}=0.2)$. Ts was found to be $12.6{ }^{\circ} \mathrm{C}$ lower (point $\mathrm{A}$, first scenario) in correspondence of cool pavement $(\mathrm{a}=0.89)$ and of a high crown density tree such as the Koeulreuteria paniculata tree $(\mathrm{a}=0.70, \mathrm{LAD}=0.75)$, whereas it was found to be $14.5^{\circ} \mathrm{C}$ lower in correspondence with grass $(\mathrm{a}=0.2)$ and the Koeulreuteria paniculata tree (point $\mathrm{A}$, second scenario).

PET was found to be $14.8^{\circ} \mathrm{C}$ lower in correspondence of the Koeulreuteria paniculata tree $(\mathrm{a}=0.70$, $\mathrm{LAD}=0.75$ ) and grass (point $\mathrm{A}$, second scenario; see Figure 7a), a similar performance of the PET value is visible in correspondence of a high crown density tree such as the Koeulreuteria paniculata tree and a high albedo pavement $(\mathrm{a}=0.89)$, where the PET is $11.8^{\circ} \mathrm{C}$ lower (point a; first scenario). However, if we consider a point without tree (e.g., point B) the PET value trends are different, in fact: in correspondence of a cool pavement with a high albedo $(\mathrm{a}=0.89)$ the PET is $1.4{ }^{\circ} \mathrm{C}$ lower, whereas it is $0.8^{\circ} \mathrm{C}$ lower in correspondence of grass only, showing a better performance of the cool pavement.

Thus, if we consider surface temperature at 13:00 in those areas of the square mostly affected by solar radiation, the most efficient strategies in terms of cooling the pavement surfaces is the cool pavement used alone (point $B$, first scenario; see Figure $6 b$ ), followed by the combination of tree and grass (point $\mathrm{A}$, second scenario; see Figure 6a).

On the other hand, if we consider the thermal comfort conditions in terms of PET at 13:00, in a point exposed to solar radiation excluded by the shades of surrounding buildings but under natural shading devices, such as the Koeulreuteria paniculata tree, the most effective design combination is represented by tree and grass, in the second scenario, with a corresponding cooling effect of $-14.8^{\circ} \mathrm{C}$, followed by cool pavement and tree, first scenario, with a corresponding cooling effect of $-11.8^{\circ} \mathrm{C}$.

From a design point of view, the present study underlines the importance of shaded areas and the positive effect of combined green and cool technologies, such as trees and cool pavements, on outdoor thermal comfort. Therefore, taking into account these observations, the findings of the study are intended for the urban planners and designers not as detailed quantitative guidelines but as designing considerations for the configuration of the urban open space. In this regard, the microclimatic analysis is relevant not in the way it offers specific quantities to apply thoroughly in a determined urban area, but in the way it informs the urban designer of the processes and behaviors related to morphological and materials factors.

Regarding the shading factor, it is important to guarantee a certain amount of shaded spaces, which depends on the climate and the use of the square. In fact, the effect of the shadow on the microclimate is local and site specific; in other words, shadow, whether derived by an artificial or natural shading object, has a very high effect in the specific local area, as visible from the ENVI-met thermal maps and from the graphs, and as previously underlined in an interesting study conducted in Stuttgart by Ketterer and Matzarakis [37].

Regarding the cool materials technologies, cool pavements showed a general upgrade of the outdoor thermal comfort conditions and a mitigation effect towards the urban surfaces temperature, albeit when applied to building walls they showed a different performance, especially regarding the related comfort conditions. Thus, further investigations are needed in order to better understand their behavior in different orientation (the surface orientation) and configurations (in relation to other materials or natural element): in fact, if we consider the solution of cool pavements and trees, the combination showed a good performance for the mitigation potential and for the thermal comfort upgrade, but the same technology when applied on a vertical surface such as a wall showed different effects on the outdoor microclimate and nearby thermal comfort.

These findings suggest different themes and directions, especially in the field of innovative and advanced materials. Particularly, it could be interesting to investigate the effect of a wall characterized by a combination of technologies: such as green wall in the lower section, at the pedestrian level, and cool materials applied on the upper part of the façades, thus influencing the microclimate and avoiding the direct negative effects the pedestrians. Regarding the vegetation, further simulations are needed in order to evaluate the performance of different trees, since the cooling effect on the outdoor environment vary considerably in green typology, location and orientation. From a methodological point of view, 
it could be interesting to test in situ the designed renovations scenarios and to carry out a field survey of the pedestrian thermal comfort. In conclusion, concerning the future developments, the observations made in this study have identified some key issues, in particular the different thermal performance of cool materials according to the surface orientation and to the combination with other cooling strategies, which require attention at the level of urban design, in addition the findings emphasize the importance to proceed with further research on the influence of urban design parameters on microclimate and comfort in a wider and more complete range of climatic conditions (eg., winter, spring, autumn), possibly in other squares in the city of Rome in order to analyze open spaces belonging to the same climate and typology of tissue but with different SVFs, and then to carry out further investigations in a wider range of locations characterized by other climates.

Acknowledgments: The authors are also grateful to Ms Silvia Cimini, Ms Arianna Marino and Ms Irene Trombetta for their help during the field data collection and to Ms Ioanna Skoufali for her help in the ENVI-met PET calculation.

Author Contributions: Letizia Martinelli conceived and conducted the experiments and analysis on the summer attendance in San Silvestro square, Flavia Laureti and Alessandra Battisti conceived the renovation scenarios, Flavia Laureti designed and performed the microclimate simulations, Flavia Laureti and Letizia Martinelli analyzed the data and wrote the paper, Alessandra Battisti supervised the research and reviewed the paper.

Conflicts of Interest: The authors declare no conflict of interest.

\section{References}

1. Santamouris, M.; Kolokotsa, D. Urban Climate Mitigation Techniques; Routledge-Earthscan: London, UK, 2016.

2. Stocker, T. Climate Change 2013: The Physical Science Basis: Working Group I Contribution to the Fifth Assessment Report of the Intergovernmental Panel on Climate Change; Cambridge University Press: Cambridge, UK; New York, NY, USA, 2014.

3. Martinelli, L.; Lin, T.-P.; Matzarakis, A. Assessment of the influence of daily shadings pattern on human thermal comfort and attendance in Rome during summer period. Build. Environ. 2015, 92, 30-38. [CrossRef]

4. Gehl, J.; Koch, J. Life Between Buildings: Using Public Space; Van Nostrand Reinhold: New York, NY, USA, 1987.

5. Katzschner, L.; Bosch, U.; Röttgen, M. Behaviour of people in open spaces in dependence of thermal comfort conditions. In Proceedings of the 23rd Conference on Passive and Low Energy Architecture (PLEA), Geneva, Switzerland, 6-8 September 2006.

6. Hwang, R.-L.; Lin, T.-P.; Matzarakis, A. Outdoor thermal comfort in university campus in hot-humid regions. In Proceedings of the Seventh International Conference on Urban Climate, Yokohama, Japan, 29 June-3 July 2009.

7. Nikolopoulou, M. Designing Open Spaces in the Urban Environment: A Bioclimatic Approach: Ruros-Rediscrovering the Urban Realm and Open Spaces; Center for Renewable Energy Sources: Attiki, Greece, 2004.

8. Lynch, K. The Image of The City; MIT Pr.: Cambridge, MA, USA, 1979.

9. Krier, R. Lo Spazio Della Città; Clup: Milano, Italy, 1982.

10. Gehl, J. Cities for People; Island Press: Washington, DC, USA, 2010.

11. Thorsson, S.; Lindqvist, M.; Lindqvist, S. Thermal bioclimatic conditions and patterns of behaviour in an urban park in Göteborg, Sweden. Int. J. Biometeorol. 2004, 48, 149-156. [CrossRef] [PubMed]

12. American Society of Heating, Refrigerating and Air-Conditioning Engineers. Thermal Environmental Conditions for Human Occupancy: ANSI/ASHRAE Standard 55-2004; ANSI: Atlanta, GA, USA, 2004.

13. Nikolopoulou, M.; Steemers, K. Thermal comfort and psychological adaptation as a guide for designing urban spaces. Energy Build. 2003, 35, 95-101. [CrossRef]

14. Kántor, N.; Unger, J. The most problematic variable in the course of human-biometeorological comfort assessment: The mean radiant temperature. Cent. Eur. J. Geosci. 2011, 3, 90-100. [CrossRef]

15. Matzarakis, A.; Rutz, F.; Mayer, H. Modelling radiation fluxes in simple and complex environments: Basics of the RayMan model. Int. J. Biometeorol. 2010, 54, 131-139. [CrossRef] [PubMed]

16. Oke, T.R. Initial Guidance to Obtain Representative Meteorological Observations at Urban Sites; World Meteorological Organization: Geneva, Switzerland, 2004.

17. Oke, T.R. Boundary Layer Climates; Routledge: London, UK; New York, NY, USA, 1987; ISBN 978-0-415-04319-9. 
18. Santamouris, M. Cooling the cities-A review of reflective and green roof mitigation technologies to fight heat island and improve comfort in urban environments. Sol. Energy 2014, 103, 682-703. [CrossRef]

19. Mihalakakou, G.; Santamouris, M.; Papanikolaou, N.; Cartalis, C.; Tsangrassoulis, A. Simulation of the Urban Heat Island Phenomenon in Mediterranean Climates. Pure Appl. Geophys. 2004, 161, 429-451. [CrossRef]

20. Kolokotsa, D.; Santamouris, M.; Zerefos, S. Green and cool roofs' urban heat island mitigation potential in European climates for office buildings under free floating conditions. SE Sol. Energy 2013, 95, 118-130. [CrossRef]

21. Yang, J.; Wang, Z.-H.; Kaloush, K.E. Environmental impacts of reflective materials: Is high albedo a 'silver bullet' for mitigating urban heat island? Renew. Sustain. Energy Rev. 2015, 47, 830-843. [CrossRef]

22. Santamouris, M. Energy and Climate in the Urban Built Environment; James \& James: London, England, 2001; ISBN 978-1-873936-90-0.

23. Erell, E.; Boneh, D.; Pearlmutter, D.; Bar-Kutiel, P. Effect of high-albedo materials on pedestrian thermal sensation in urban street canyons in hot climates. In Proceedings of the 29th Conference, Sustainable Architecture for a Renewable Future (PLEA2013), Munich, Germany, 10-12 September 2013.

24. Cartalis, C.; Synodinou, A.; Proedrou, M.; Tsangrassoulis, A.; Santamouris, M. Modifications in energy demand in urban areas as a result of climate changes: an assessment for the southeast Mediterranean region. Energy Convers. Manag. 2001, 42, 1647-1656. [CrossRef]

25. Akbari, H.; Konopacki, S. Energy effects of heat-island reduction strategies in Toronto, Canada. Energy 2004, 29, 191-210. [CrossRef]

26. Vallati, A.; Vollaro, A.D.L.; Golasi, I.; Barchiesi, E.; Caranese, C. On the Impact of Urban Micro Climate on the Energy Consumption of Buildings. Energy Procedia 2015, 82, 506-511. [CrossRef]

27. Organisation de Coopération et de Développement Économiques. Climate Change Mitigation What Do We Do?; OECD: Paris, France, 2008.

28. Shashua-Bar, L.; Hoffman, M.E. Vegetation as a climatic component in the design of an urban street: An empirical model for predicting the cooling effect of urban green areas with trees. Energy Build. 2000, 31, 221-235. [CrossRef]

29. Lindberg, F.; Grimmond, C.S.B. The influence of vegetation and building morphology on shadow patterns and mean radiant temperatures in urban areas: model development and evaluation. Theor. Appl. Climatol. 2011, 105, 311-323. [CrossRef]

30. Akbari, $\mathrm{H}$. Shade trees reduce building energy use and $\mathrm{CO} 2$ emissions from power plants. Environ. Pollut. 2002, 116, S119-S126. [CrossRef]

31. Berry, R.; Livesley, S.J.; Aye, L. Tree canopy shade impacts on solar irradiance received by building walls and their surface temperature. Build. Environ. 2013, 69, 91-100. [CrossRef]

32. Srivanit, M.; Hokao, K. Evaluating the cooling effects of greening for improving the outdoor thermal environment at an institutional campus in the summer. Build. Environ. 2013, 66, 158-172. [CrossRef]

33. Upreti, R.; Wang, Z.-H.; Yang, J. Radiative shading effect of urban trees on cooling the regional built environment. UFUG Urban For. Urban Green. 2017, 26, 18-24. [CrossRef]

34. Saaroni, H.; Amorim, J.; Hiemstra, J.; Pearlmutter, D. Urban Green Infrastructure as a tool for urban heat mitigation: Survey of research methodologies and findings across different climatic regions. UCLIM Urban Clim. 2018, 24, 94-110. [CrossRef]

35. Roy, S.; Byrne, J.; Pickering, C. A systematic quantitative review of urban tree benefits, costs, and assessment methods across cities in different climatic zones. UFUG Urban For. Urban Green. 2012, 11, 351-363. [CrossRef]

36. Shashua-Bar, L.; Tsiros, I.X.; Hoffman, M. Passive cooling design options to ameliorate thermal comfort in urban streets of a Mediterranean climate (Athens) under hot summer conditions. BAE Build. Environ. 2012, 57, 110-119. [CrossRef]

37. Ketterer, C.; Matzarakis, A. Human-biometeorological assessment of heat stress reduction by replanning measures in Stuttgart, Germany. Landsc. Urban Plan. 2014, 122, 78-88. [CrossRef]

38. Mayer, H. Workshop “Ideales Stadtklima” am 26. Oktober 1988 in München. DMG Mitteilungen 3/89; 1989, pp. 52-54. Available online: http://www.geographie.uni-freiburg.de/publikationen/fgh-index (accessed on 10 December 2017).

39. Cheung, P.K.; Jim, C. Comparing the cooling effects of a tree and a concrete shelter using PET and UTCI. Build. Environ. 2018, 130, 49-61. [CrossRef] 
40. Levinson, R.; Akbari, H.; Konopacki, S.; Bretz, S. Inclusion of cool roofs in nonresidential Title 24 prescriptive requirements. Energy Policy 2005, 33, 151-170. [CrossRef]

41. Bretz, S.; Akbari, H.; Rosenfeld, A.; Taha, H. Implementation of Solar-Reflective Surfaces: Materials and Utility Programs; Lawrence Berkeley Lab.: Berkeley, CA, USA, 1992.

42. Kolokotsa, D.; Maravelaki-Kalaitzaki, P.; Papantoniou, S.; Vangeloglou, E.; Saliari, M.; Karlessi, T.; Santamouris, M. Development and analysis of mineral based coatings for buildings and urban structures. SE Sol. Energy 2012, 86, 1648-1659. [CrossRef]

43. Levinson, R.; Berdahl, P.; Akbari, H. Solar spectral optical properties of pigments-Part I: model for deriving scattering and absorption coefficients from transmittance and reflectance measurements. Sol. Energy Mater. Sol. Cells 2005, 89, 319-349. [CrossRef]

44. Karlessi, T.; Santamouris, M.; Apostolakis, K.; Synnefa, A.; Livada, I. Development and testing of thermochromic coatings for buildings and urban structures. Sol. Energy 2009, 83, 538-551. [CrossRef]

45. Karlessi, T.; Santamouris, M.; Synnefa, A.; Assimakopoulos, D.; Didaskalopoulos, P.; Apostolakis, K. Development and testing of PCM doped cool colored coatings to mitigate urban heat island and cool buildings. Build. Environ. 2011, 46, 570-576. [CrossRef]

46. Akbari, H.; Cartalis, C.; Santamouris, M.; Synnefa, A.; Kolokotsa, D.; Muscio, A.; Pisello, A.L.; Rossi, F.; Wong, N.H.; Zinzi, M. Local climate change and urban heat island mitigation techniques-The state of the art. J. Civ. Eng. Manag. 2016, 22, 1-16. [CrossRef]

47. Akbari, H.; Matthews, H.D.; Seto, D. The long-term effect of increasing the albedo of urban areas. Environ. Res. Lett. 2012, 7. [CrossRef]

48. Rossi, F.; Bonamente, E.; Nicolini, A.; Anderini, E.; Cotana, F. A carbon footprint and energy consumption assessment methodology for UHI-affected lighting systems in built areas. Energy Build. 2016, 114, 96-103. [CrossRef]

49. Pisello, A.L. State of the art on the development of cool coatings for buildings and cities. Sol. Energy 2017, 144, 660-680. [CrossRef]

50. Santamouris, M.; Synnefa, A.; Karlessi, T. Using advanced cool materials in the urban built environment to mitigate heat islands and improve thermal comfort conditions. Sol. Energy 2011, 85, 3085-3102. [CrossRef]

51. Synnefa, A.; Santamouris, M.; Livada, I. A study of the thermal performance of reflective coatings for the urban environment. SE Sol. Energy 2006, 80, 968-981. [CrossRef]

52. Santamouris, M.; Gaitani, N.; Spanou, A.; Saliari, M.; Giannopoulou, K.; Vasilakopoulou, K.; Kardomateas, T. Using cool paving materials to improve microclimate of urban areas-Design realization and results of the flisvos project. BAE Build. Environ. 2012, 53, 128-136. [CrossRef]

53. Kolokotsa, D.-D.; Santamouris, M.; Akbari, H. Advances in the Development of Cool Materials for the Built Environment; Bentham Science Publishers: Sharjah, United Arab Emirates, 2013.

54. Georgakis, C.; Zoras, S.; Santamouris, M. Studying the effect of "cool" coatings in street urban canyons and its potential as a heat island mitigation technique. SCS Sustain. Cities Soc. 2014, 13, 20-31. [CrossRef]

55. Development of Cool Pavement with Dark Colored High Albedo Coating. Available online: https://ams. confex.com/ams/AFAPURBBIO/techprogram/paper_79804.htm (accessed on 10 January 2018).

56. Piselli, C.; Castaldo, V.; Pigliautile, I.; Pisello, A.; Cotana, F. Outdoor comfort conditions in urban areas: on citizens' perspective about microclimate mitigation of urban transit areas. Sustain. Cities Soc. 2018. [CrossRef]

57. Erell, E.; Pearlmutter, D.; Boneh, D.; Kutiel, P.B. Effect of high-albedo materials on pedestrian heat stress in urban street canyons. UCLIM Urban Clim. Part 2 2014, 10, 367-386. [CrossRef]

58. Chatzidimitriou, A.; Yannas, S. Microclimate development in open urban spaces: The influence of form and materials. ENB Energy Build. 2015, 108, 156-174. [CrossRef]

59. Köppen, W. The thermal zones of the Earth according to the duration of hot, moderate and cold periods and to the impact of heat on the organic world. Meteorol. Z. 2011, 20, 351-360. [CrossRef] [PubMed]

60. Mayer, H.; Höppe, P. Thermal comfort of man in different urban environments. Theor. Appl. Climatol. 1987, 38, 43-49. [CrossRef]

61. Davenport, A.G.; Oke, T.R.; Grimmond, C.S.B. Estimating the roughness of cities and sheltered country. In Proceedings of the 12th Conference on Applied Climatology, Asheville, North Carolina, Boston, MA, USA, 8-11 May 2000; pp. 96-99. 
62. Nikolopoulou, M.; Lykoudis, S. Use of outdoor spaces and microclimate in a Mediterranean urban area. Build. Environ. 2007, 42, 3691-3707. [CrossRef]

63. Spagnolo, J.; de Dear, R.J. A field study of thermal comfort in outdoor and semi-outdoor environments in subtropical Sydney Australia. Build. Environ. 2003, 38, 721-738. [CrossRef]

64. Gobakis, K.; Kolokotsa, D.; Maravelaki-Kalaitzaki, N.; Perdikatsis, V.; Santamouris, M. Development and analysis of advanced inorganic coatings for buildings and urban structures. ENB Energy Build. 2015, 89, 196-205. [CrossRef]

65. Höppe, P. The physiological equivalent temperature: A universal index for the biometeorological assessment of the thermal environment. Int. J. Biometeorol. 1999, 43, 71-75. [CrossRef] [PubMed]

66. Matzarakis, A.; Martinelli, L.; Ketterer, C. Relevance of Thermal Indices for the Assessment of the Urban Heat Island. In Counteracting Urban Heat Island Effects in a Global Climate Change Scenario; Springer: Cham, Switzerland, 2016; pp. 93-107; ISBN 978-3-319-10424-9.

67. Cohen, P.; Potchter, O.; Matzarakis, A. Human thermal perception of Coastal Mediterranean outdoor urban environments. JAPG Appl. Geogr. 2013, 37, 1-10. [CrossRef]

68. Kantor, N.; Unger, J. Benefits and opportunities of adopting GIS in thermal comfort studies in resting places: An urban park as an example. Landsc. URBAN Plan. 2010, 98, 36-46. [CrossRef]

69. Gulyás, Á.; Unger, J.; Matzarakis, A. Assessment of the microclimatic and human comfort conditions in a complex urban environment: Modelling and measurements. Build. Environ. 2006, 41, 1713-1722. [CrossRef]

70. Matzarakis, A.; Mayer, H.; Iziomon, M.G. Applications of a universal thermal index: Physiological equivalent temperature. Int. J. Biometeorol. 1999, 43, 76-84. [CrossRef] [PubMed]

71. Chen, Y.-C.; Matzarakis, A. Modification of physiologically equivalent temperature. J. Heat Isl. Inst. Int. 2014, 9, 2. [CrossRef]

72. Lin, T.-P. Thermal perception, adaptation and attendance in a public square in hot and humid regions. BAE Build. Environ. 2009, 44, 2017-2026. [CrossRef]

73. Huttner, S.; Bruse, M.; Dostal, P. Using ENVI-met to simulate the impact of global warming on the microclimate in central European cities. In Proceedings of the 5th Japanese-German Meeting on Urban Climatology, Freiburg, Germany, 6-8 October 2008; pp. 307-312.

74. Winter Release 2017-New Features. ENVI_MET. Available online: http://www.envi-met.com/winterrelease-2017-new-features / (accessed on 10 December 2017). 